
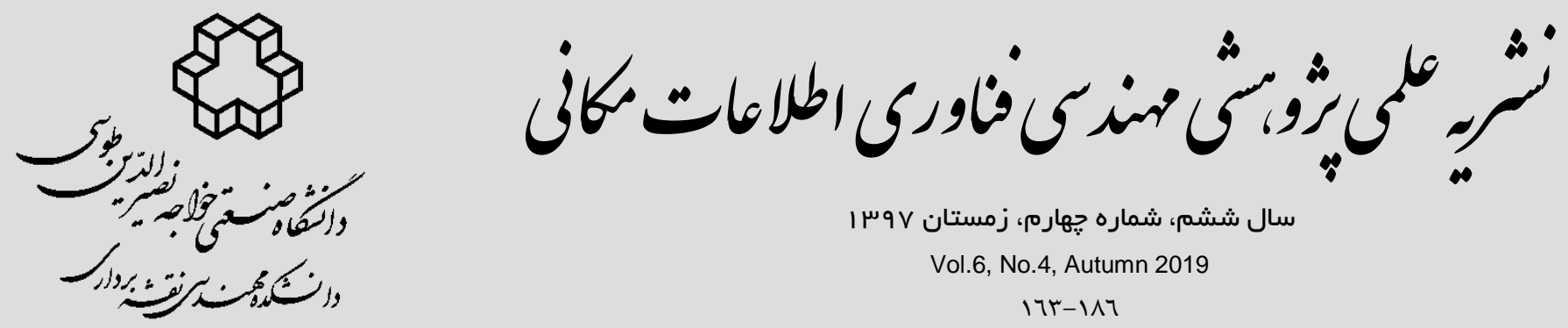

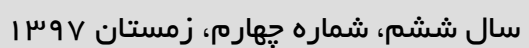

Vol.6, No.4, Autumn 2019

$17 r-111$

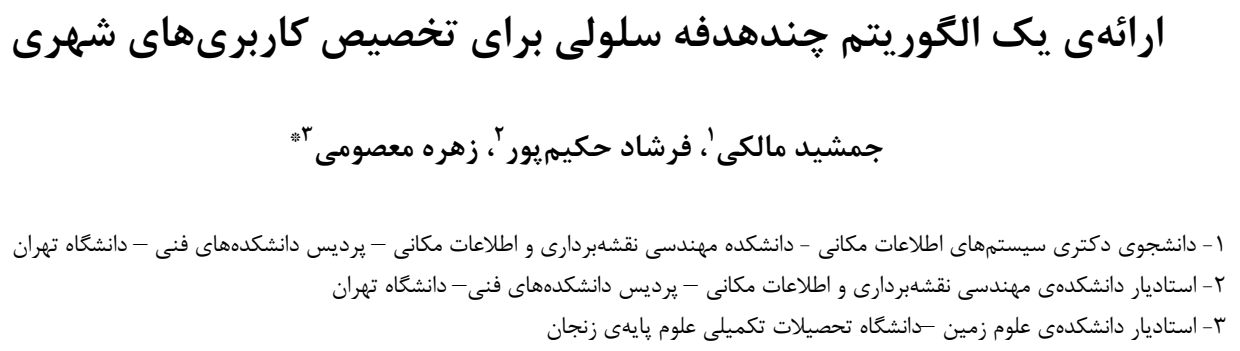

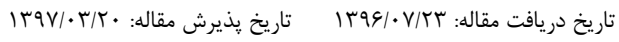

جكيده

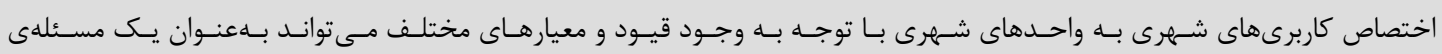

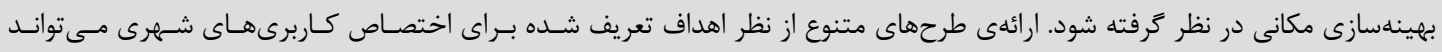

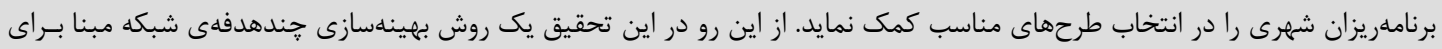

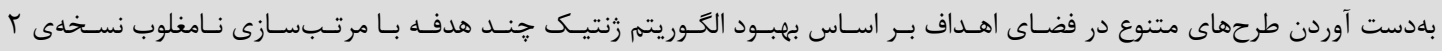

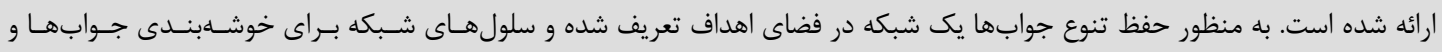

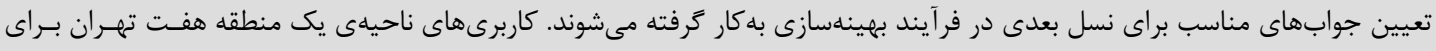

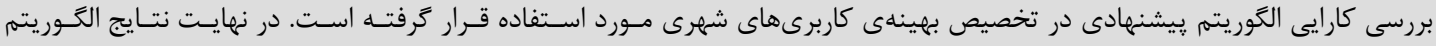

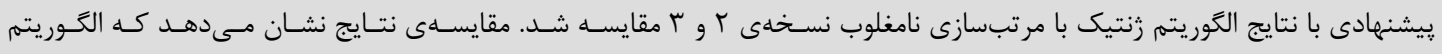

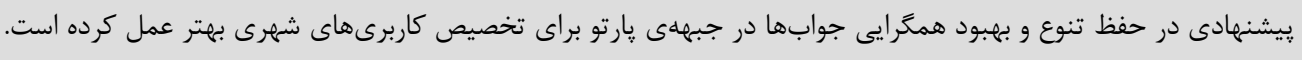

كليدوازهها: تخصيص كاربرىهاى شهرى، الكوريتم زنتيك با مرتبسازى نامغلوب شبكهمبنا، بهينهسازى קند هدفه، سيستمهاى حامى تصميمَّيرى. 
بهينه دارند. تعامل بـين تصـميمَيــران و مـذاكره بــين

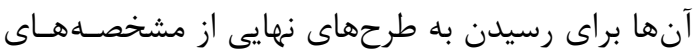

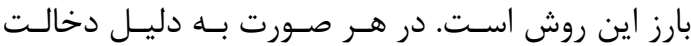

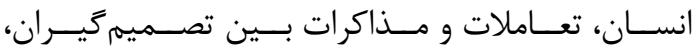

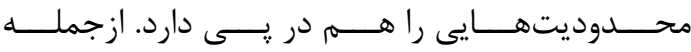

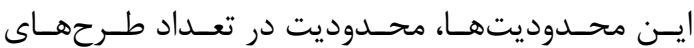
ييشنهادى و نحوهى ارزيابى دقيق اين طرحها و احتمال

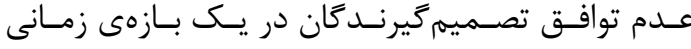
مشخص مى تواند باشد.

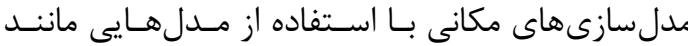

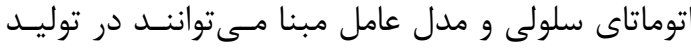

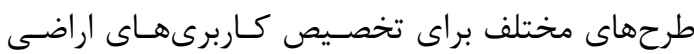

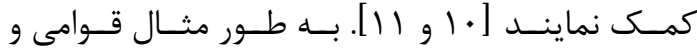

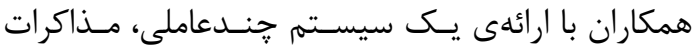

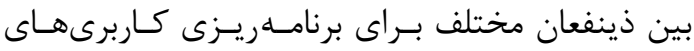

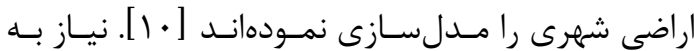

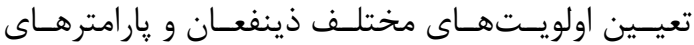
مختلف مدل بهمنظور ايجاد كزينههاى مختلف از نقـاط ضعف اين مدل ها محسوب مىشود. تخصيص كاربرىهـاى كونـاكون بـه واحـدهاى شهـرى

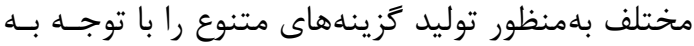

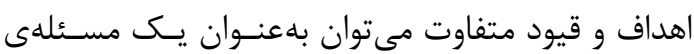

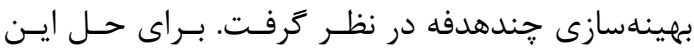

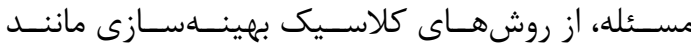

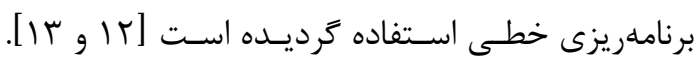

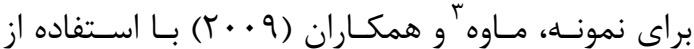

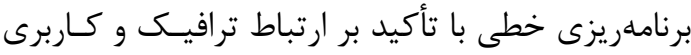

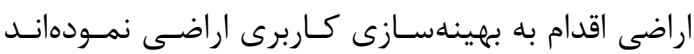
[Y [ []. وجود اهداف غيرخطى و قيـود مختلـف در كنـار

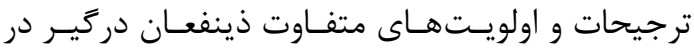

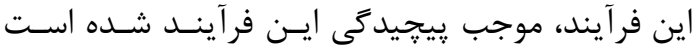

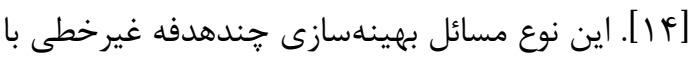
ييجيدگى بالا نياز به روشهاى بهينهسـازى فرابتكـارى
|- 1- مقدمه

فر آيند تصميم كيرى در تخصيص بهينهى كـاربرىهـاى شهرى بهعنوان هستهى اصلى برنامهريزى كاربرى

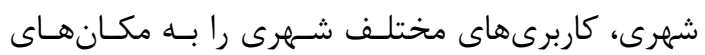
مطلـوب اختصــاص داده و موجــب سـاماندهى مكـانى فعاليتهاى شـهرى بـر اسـاس خواسـتهـــا و نيازهـاى

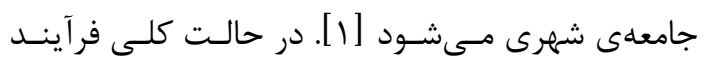

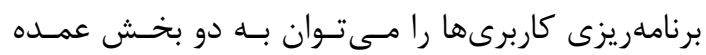

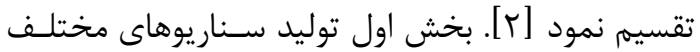

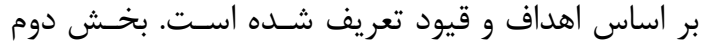

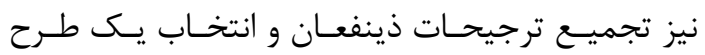
كاربرى اراضى نهايى است. هستهى اصلى برنامـهريـزى

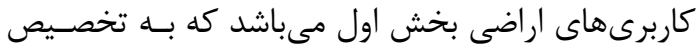

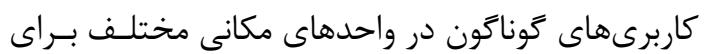

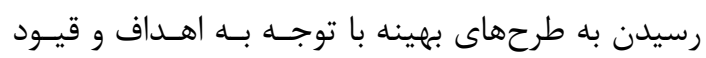

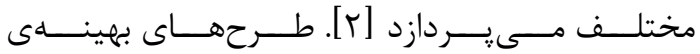

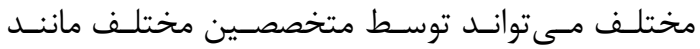

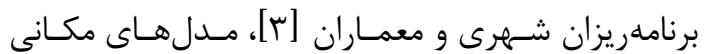

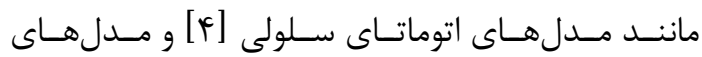

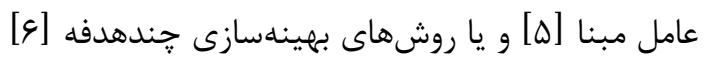

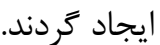
طرحهاى بهينه توسط متخصصين با تشكيل كار كاههاى

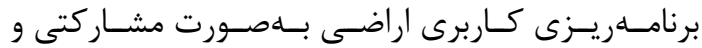

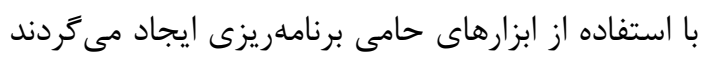

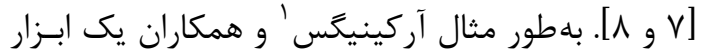

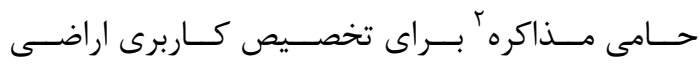

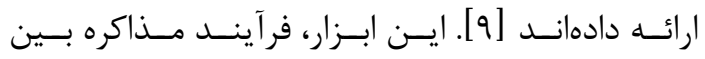

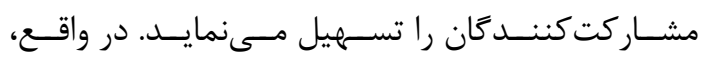

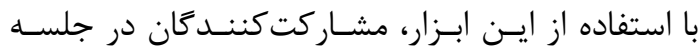

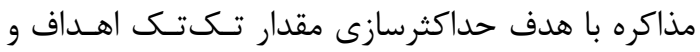

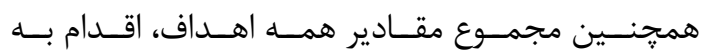
تغيير كاربرىهاى نقشه نموده و سعى در ارائه طرحهاى

\footnotetext{
${ }^{1}$ Arciniegas

${ }^{2}$ Negotiation Support Tool
} 


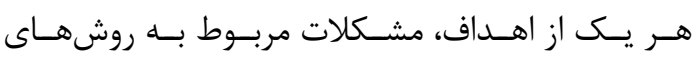

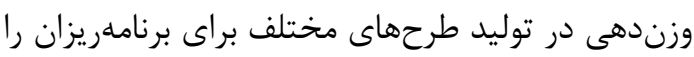

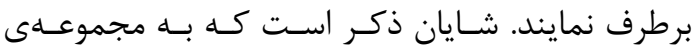

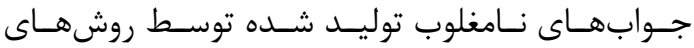
بهينهسازى جندهدفه جبهلهى جوابهاى يـارتو كوينـد.

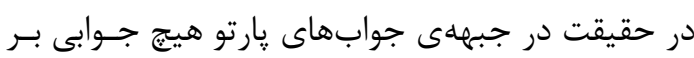

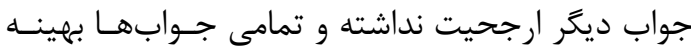

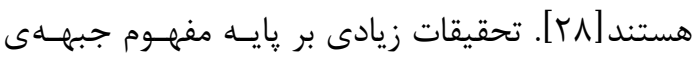

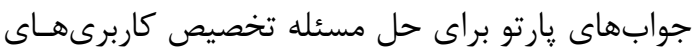

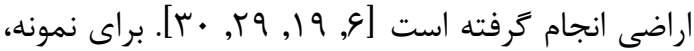

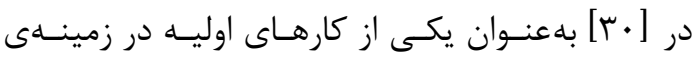

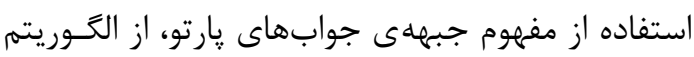

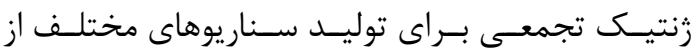
جيدمان كاربرىهاى اراضى شـهرى بـراى برنامـهريـزان

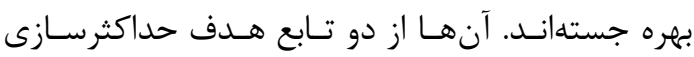
تناسب قطعات براى توسـعه و حداكثرسـازى سـاز كارى بين واحدهاى مكانى استفاده نمودهاند. كائو َّ و همكاران

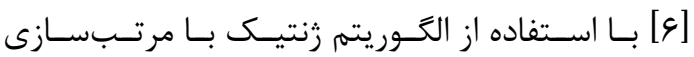

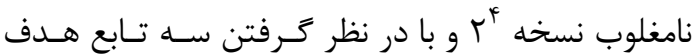

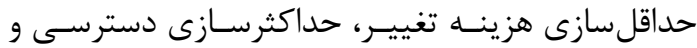

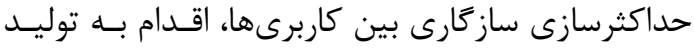

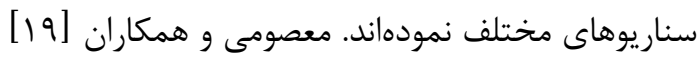

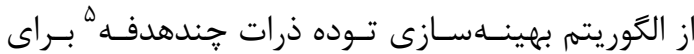

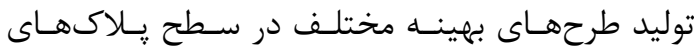

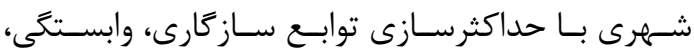

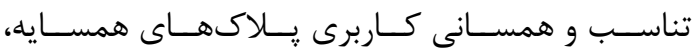
استفاده نمودهاند. اين روشهاى بهينهسازى קُندهدفـه بكار كرفته شده در تحقيقات اخير، تنها زمانى كه تعداد

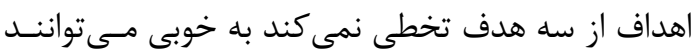

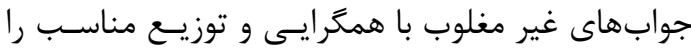

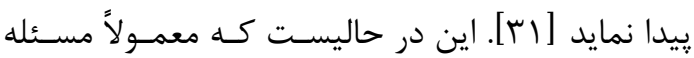

\footnotetext{
${ }^{3} \mathrm{CaO}$

4 Non-dominated Sorting Genetic Algorithm II (NSGA-II)

${ }^{5}$ Multi-objective Particle Swarm Optimization
}

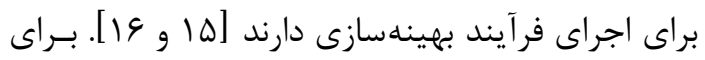
به دست آوردن طرحهاى بهينه بهصورت يكى مسـئلهى جندهدفه غير خطى با استفاده از روشهاى فرا ابتكارى،

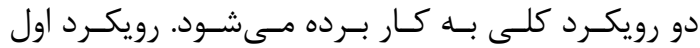

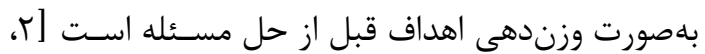

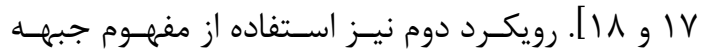

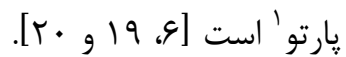

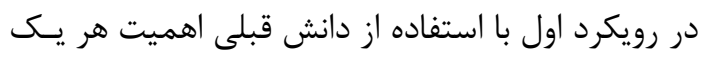

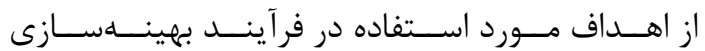
مشخص شده و با تجميع اهداف، مسئلهى بهينسهسازى جندهدفه تبديل به يك مسئلهى بهينهاسازى تك هدفه

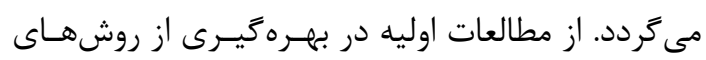

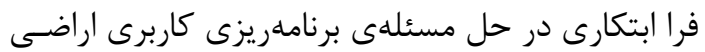

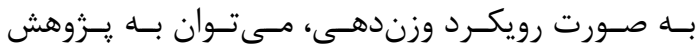

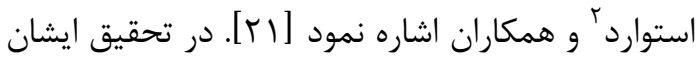
از روش برنامهريزى آرمانى بهعنوان يك روش وزندهى،

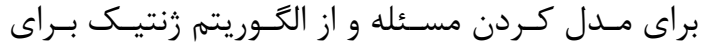

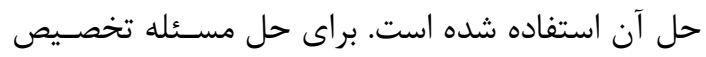
كاربرىهاى اراضى بلهصورت وزندهى، به الكَوريتمهـاى استى

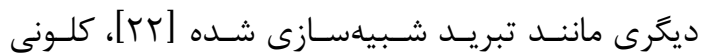

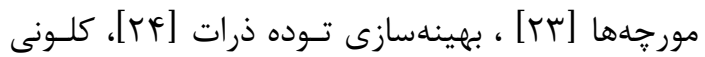

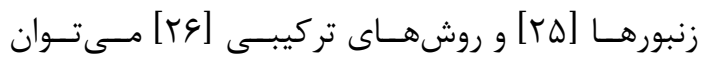
اشاره نمود. مشكل اصلى اين روشها وابستخى آنها بـهـ

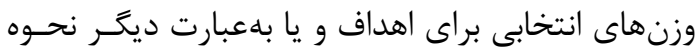

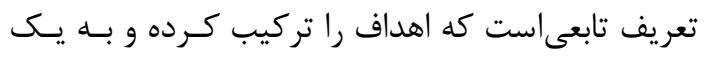
هدف تبديل مى كند. مشكل ديكر روشهـاى وزندهـى تهي،

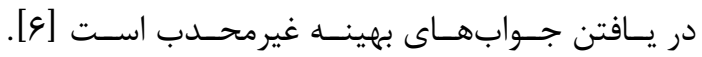

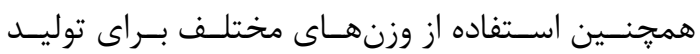

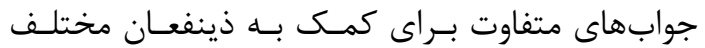

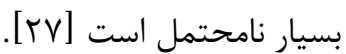

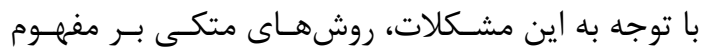

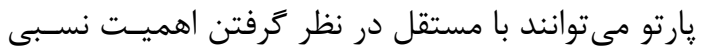

\footnotetext{
${ }^{1}$ Pareto Front

${ }^{2}$ Stewart
} 


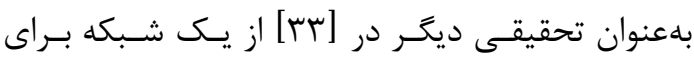

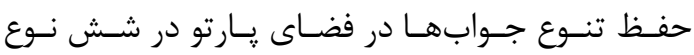

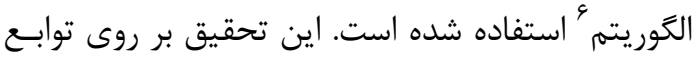

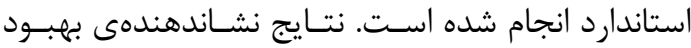
توزيع جوابهـاى نهـايى در اسـتفاده از مفهـوم شـبكه ست. با توجـهـ بــه تحقيقـات كذشـــه، اسـتفاده از روشهــاى

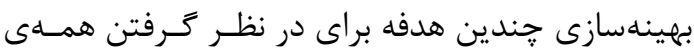

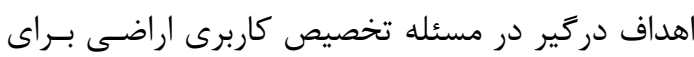
رسيدن به جوابهايى با توزيع مناسب در فضـاى يـارتو اجتنابنايذير است. از طرفى در برخى تحقيقـات نشان إنسان

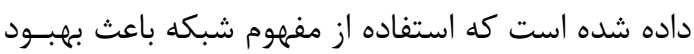

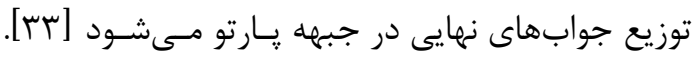
بر همين اساس، در اين تحقيق يك روش جندين دين هدفائه بر مبناى الكوريته زنتيك با مرتبسازى نامغلوب نسخه r و مفهوم شبكه براى حـل مسـئله تخصسيص كـاربرى اراضى با اهداف زياد به منظور يافتن جوابهاى متنوع و

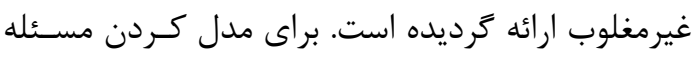
تخصيص كاربرى اراضى از ينج هدف كـه در تحقيقـات

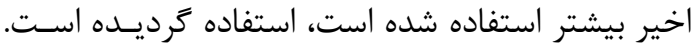
اهداف در نظر كرفته شده شامل حداكثرسازى سازكارى

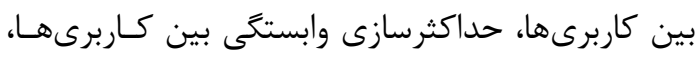

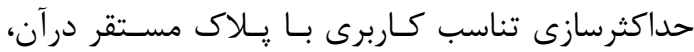
حداكثرسـازى ميـزان همســانى كـاربرىهـاى مجـاور و و

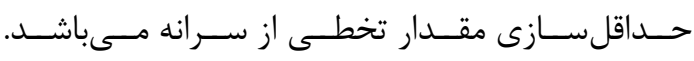

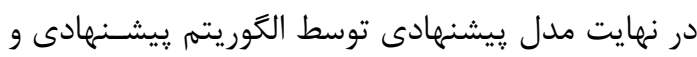

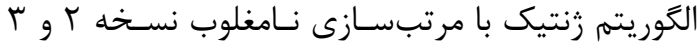

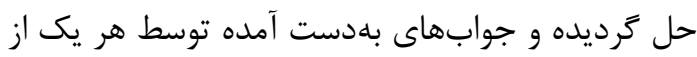
الكوريتمها باهم مقايسه تَرديده است.

NSGA-II استفاده شده در اين تحقيق نيستند.
تخصسيص كـاربرىهـاى اراضـى بــه اهــداف متعـددى

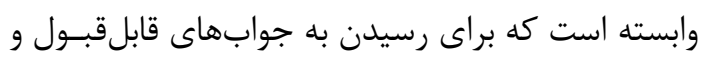

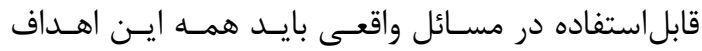

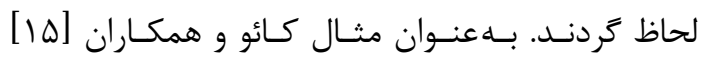
براى مدلسازى اين مسئله از هشت هدف حداكثرسازى توليد ناخالص داخلـى، حـداقلســازى تغييـرات زمــين،

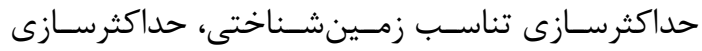

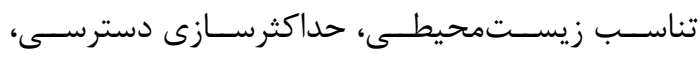

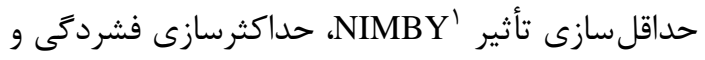
حداكثرسازى سازكارى استفاده نمودهاند.

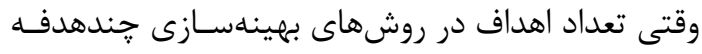

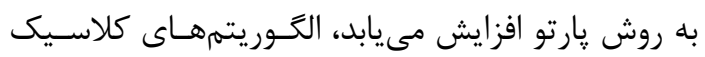

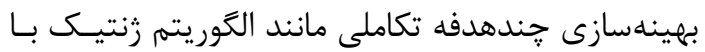

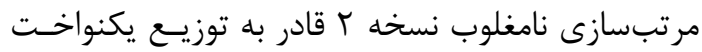
جوابها در فضاى يارتو نمىباشند. ازاينرو در تحقيقات اخير، روشهاى مختلفى براى برخورد با مسائل جندين

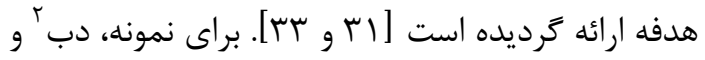

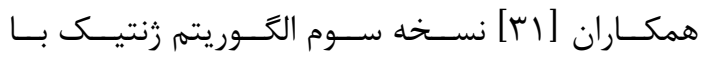

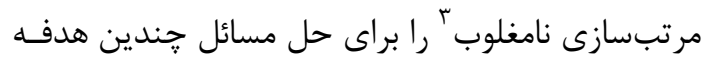

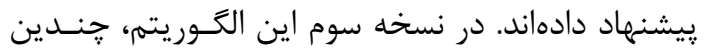

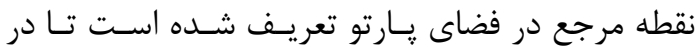
توزيع هرجه بهتر جوابها در فضاى يارتو كمك نمايــد.

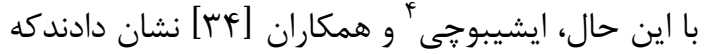

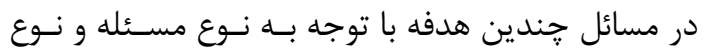

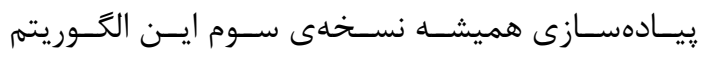

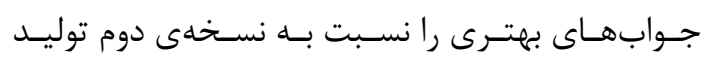

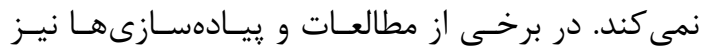

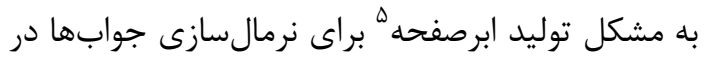

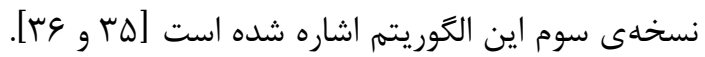

\footnotetext{
${ }^{1}$ Not In My Back Yard

${ }^{2}$ Deb

3 Non-dominated Sorting Genetic Algorithm III (NSGA-III)

${ }^{4}$ Ishibuchi

${ }^{5}$ Hyperplane
} 


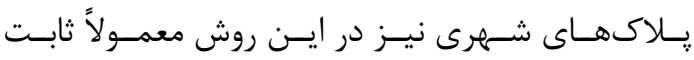

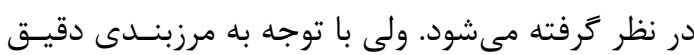

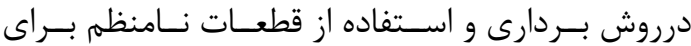

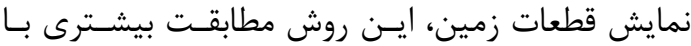

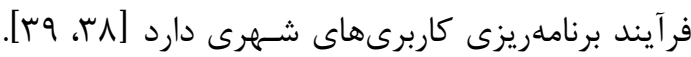
براى تعريف همسايكى هاى مختلف در دادهائ بـردارى

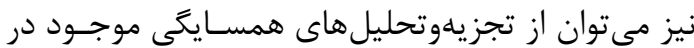
محيط سيستمهاى اطلاعات مكـانى اسـتفاده نمـود. در اين تحقيق با توجه تخصسيص كـاربرىهـاى شهرى در اطراع

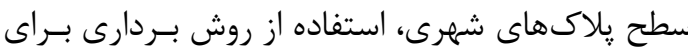

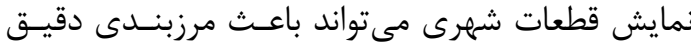

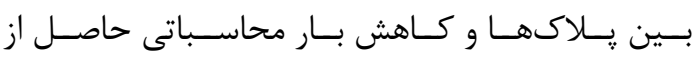

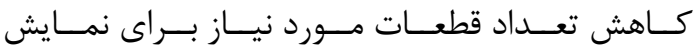
يلاكىهاى شهرى شود. بنابراين در اين تحقيـق از روش

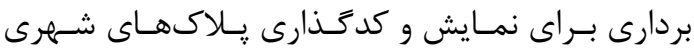

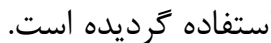
معيارها و قيود مختلفى را مى توان در مسئله تخصسيص كرديد است

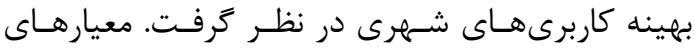
زيادى در تحقيقات كذشته براى تخصيص كاربرىهـاى دئه

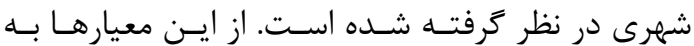

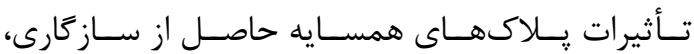

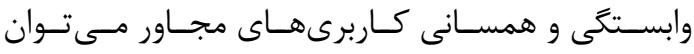

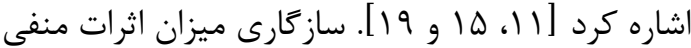

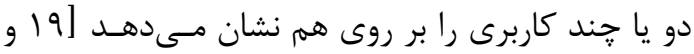

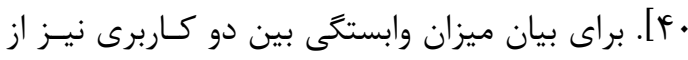

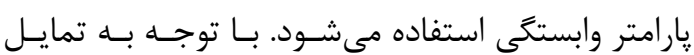
كـاربرىهـاى مختلـف بــراى حضـور در كنـار كـاربرى

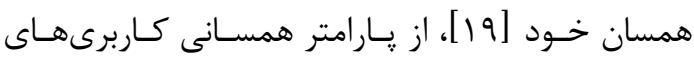
مجاور براى سنجش ميزان همسانى كاربرىهـا در يـك هـ

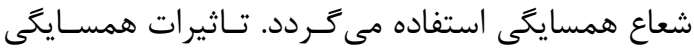

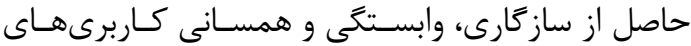
مجاور را مىتوان در قالب سه هدف مجزا و با روابط زير

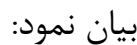

ץ- مدلسازى تخصيص كاربرىهاى شهرى

بامنظور مدلسازى تخصيص كاربرىهاى شهرى ابتـدا

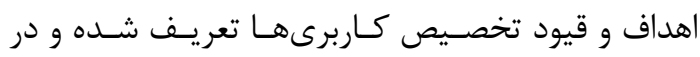

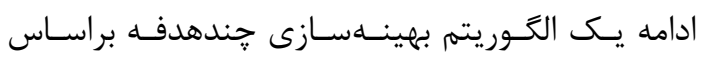
شبكهبندى فضاى اهداف معرفى گرديده است.

\section{ץ-1- اهداف و قيود تخصيص كاربرىهاى شهرى}

تخصيص بهينه كاربرىهاى شهرى مى توانـد بـه عنــوان يك فرآيند تخصيص كاربرىهاى كونـاكون بـه قطعـات

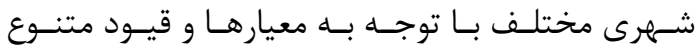
تعريف شود. در اين فرآيند نحوه تعريف قطعات شهرى

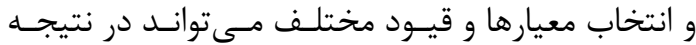

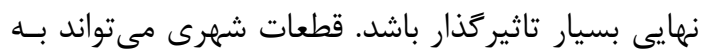
صورت يك شبكه منظم رسترى و يا به صورت قطعـات

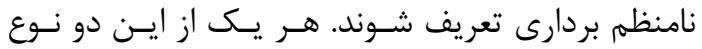

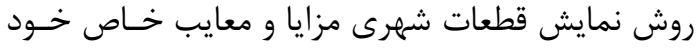
را دارد. استفاده از شبكه منظم رسـترى باعـث سههولت

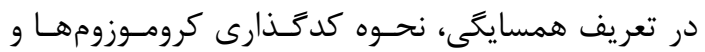

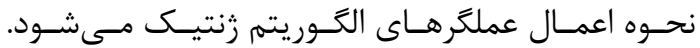

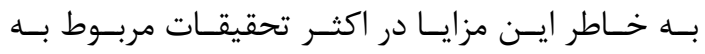
برنامهريزى كاربرىها از اين روش براى نمايش قطعـات

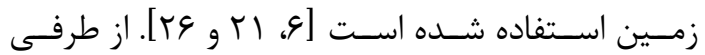
استفاده از روش رسترى براى نمـايش قطعـات شهرى السيت

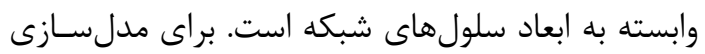
جزئيات قطعات شهرى مىبايست از شبكه با سلولهاى كو جك استفاده نمود، كه باعث افزايش تعداد سلولهاى

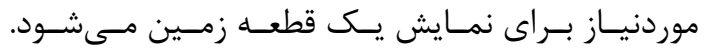
همجنين با افزايش تعداد سلولها بار محاسباتى مدل به به به صورت تصاعدى افزايش مى يابد. استفاده از سـلولهـاى تعائ

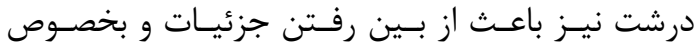

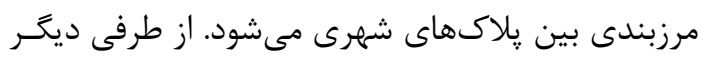

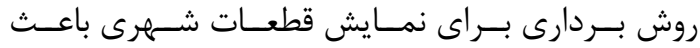

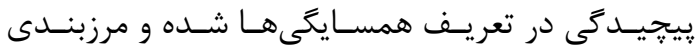


Compability $=\left\{\frac{1}{\mathrm{n}}\left(\sum_{i=1}^{n} \frac{1}{n_{i}} \sum_{j=1}^{n_{i}} \alpha_{i j} \times C_{i j}\right)+\operatorname{Minimum}\left(\sum_{j=1}^{n_{i}} \alpha_{i j} \times C_{i j}\right)\right\}$

Compability $=\left\{\frac{1}{\mathrm{n}}\left(\sum_{i=1}^{n} \frac{1}{n_{i}} \sum_{j=1}^{n_{i}} \alpha_{i j} \times D_{i j}\right)+\operatorname{Minimum}\left(\sum_{j=1}^{n_{i}} \alpha_{i j} \times D_{i j}\right)\right\}$

(T) رابطه

Compactness $=\frac{1}{n}\left(\sum_{i=1}^{n} \frac{\operatorname{sim}_{i}}{n_{i}}\right)$

رابطه (r)

اين يارامترهـا مسىتـوان مقـدار مناســبت فيزيكسى هـر

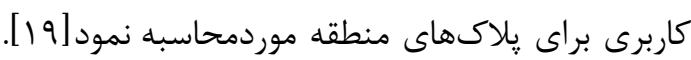

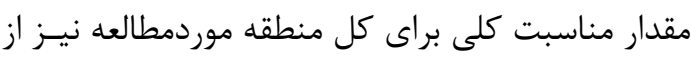
رابطه زير قابلمحاسبه است. (ابطه (1) Suitabilit y $=\left\{\frac{1}{\mathrm{n}}\left(\sum_{i=1}^{n} S_{i, c_{i}}\right)+\operatorname{Minimum}\left(S_{i, c_{i}}\right)\right\}$ در رابطه (4) مقدار

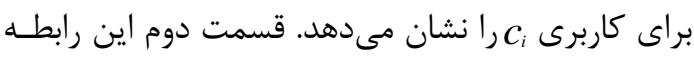

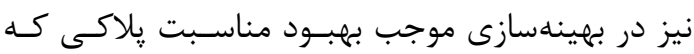
كمترين مناسبت را دارد، مىشود.

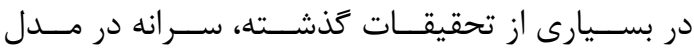

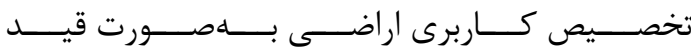

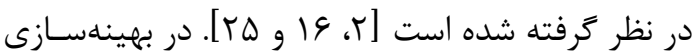

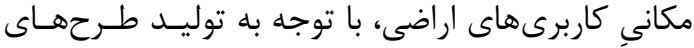

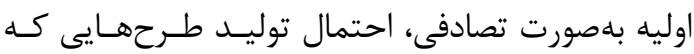

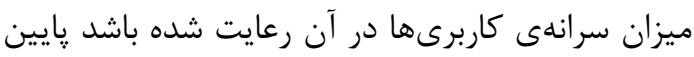
است و از نظر قيد سرانه اكثر طرحهـا نـامعتبر هسـتند. بنابراين در نظر ترفتن سرانه به عنوان قيد و استفاده از مقدار تخطى از قيد براى انتخاب جوابهاى نـامعتبر بـا

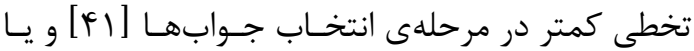

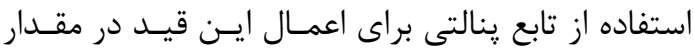

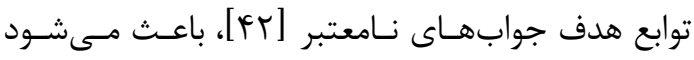
اهداف ديكر از ارزش كمترى برخـوردار شـده و تمركـز اصلى بهينهسازى در حالت קندهدفه فقط روى كمينـه كردن مقدار تخطى از سرانه قرار كيرد. همجنين تعـداد

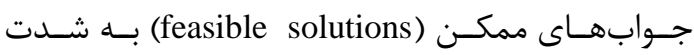

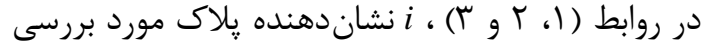

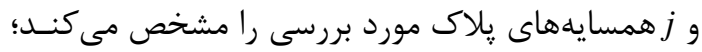

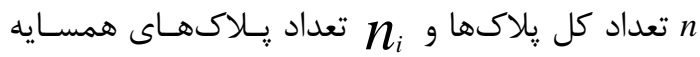

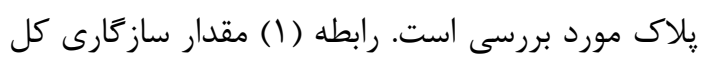

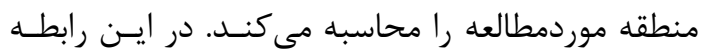

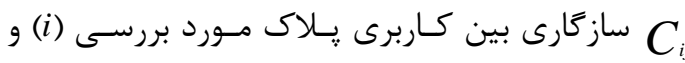

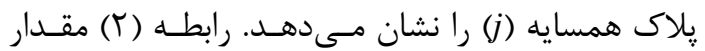
وابستخى كل منطقه موردمطالعه را محاسـبه مسى كنـد. در اين رابطه $D_{i j}$

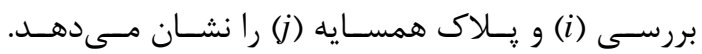
رابطه (ب) نيز ميزان همسانى كل كاربرىهاى مجـاور را

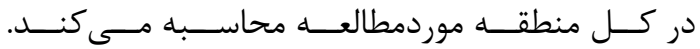
در اين رابطه

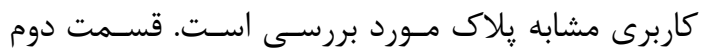
روابط (I، Y) براى حداكثرسازى مقدار حداقل معيارهـا است. وجود ايسـن بخـش از روابـط موجـب مسىشـود تـا

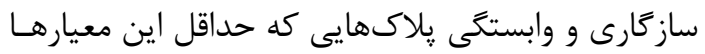

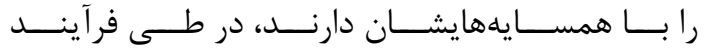
بهينهسازى بهبود يابد.

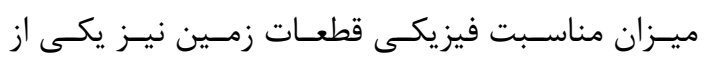

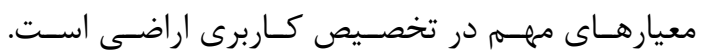
مناسبت فيزيكى ميزان انطباق فيزيكى و زيستمحيطى ديطى دئي

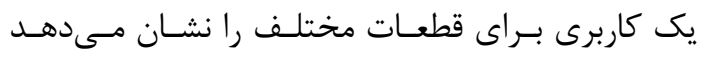

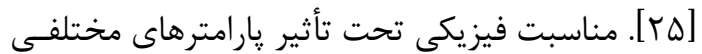

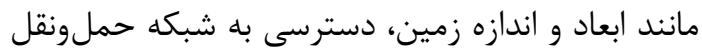

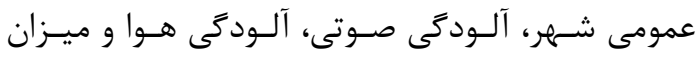

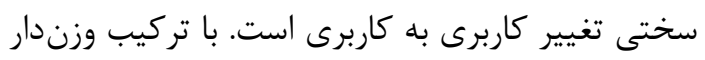


1- قيد مربوط به مساحت كاربرىها: در اين نـوع قيـد، حداكثر و حداقل مساحت يلاك شهرى كه مىتواند يذيراى كاربرى مــوردنظر باشــ، مشـخص گرديـده

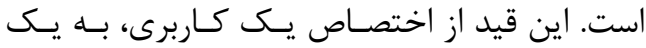

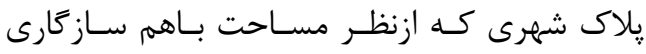
ندارند، جلو ئرى مى كند.

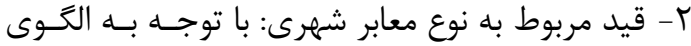

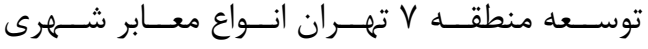
تعريف شده و نوع كاربرىهاى هـمهـــوار معـابر نيـز

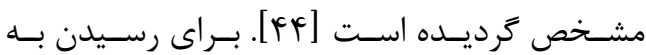
جيدمان بهينه كاربرىها، بهطـورى كــه منطبـق بــا

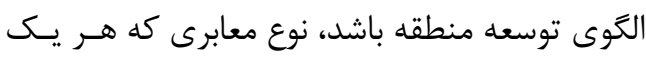

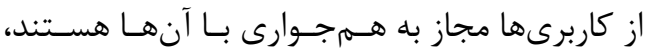

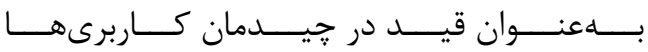
لماظ گَرديده است.

اين قيود در بهينهسازى مكانى كاربرىهاى شـهرى، در

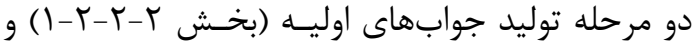

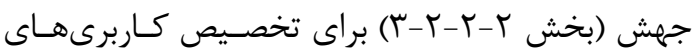
قابلقبول براى يلاكهاى شهرى به كار برده مى شوند.

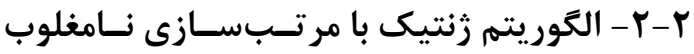
شبكهمبنا براى تخصيص بهينه كاربرىهاى اراضى شهرى

در اين قسمت يك الكَوريتم بهينهسازى جنــدين هدفــه

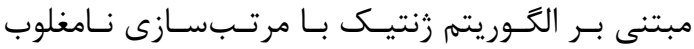

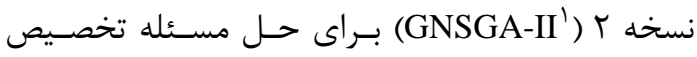
بهينه كاربرىهاى اراضـى شـهرى ارائـه گرديـده اسـت.

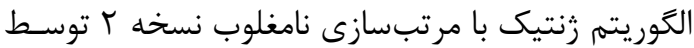

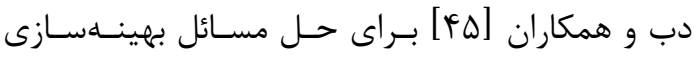

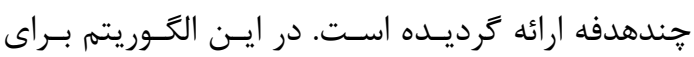
حفظ تنوع جوابها در فضاى يارتو از مفهـومى بـهـ نـام

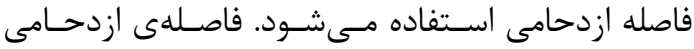

1 Grid-based Non-dominated Sorting Genetic Algorithm
كاهش ييدا مسى كنــــ از ايـنـرو در ايـن مطالعـهـ مقـدار تخطى از سرانه به صورت يك هدف مجزا در نظر زرفته شده است تا همزمـان بـا حداكثرسـازى اهـداف ديخــر، مقدار تخطى از سرانه كمينـهـ گَــدد. ميـزان تخطـى از سرانه را مى توان به صورت رابطهى (ه) محاسبه نمود. $C V=\sum_{i=1}^{m} V_{c_{i}} \quad$ (ه)

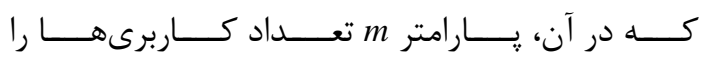
مشخص مى كنــد. يـارامتر ${ }^{\prime}$

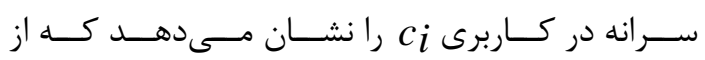
طريق رابطهى (9) محاسبه مى شود: رابطه (c)

$V_{c_{i}}=\left\{\begin{array}{l}\frac{\min A_{i}-A_{i}}{\min A_{i}} \text { for } A_{i}<\min A_{i} \\ \frac{A_{i}-\max A_{i}}{\max A_{i}} \text { for } A_{i}>\max A_{i}\end{array}\right.$ يارامتر max $A_{i} \min A_{i}$ حداقل و حداكثر مقـدار مساحت قابلقبول براى كاربرى ${ }$ است كه بـا ضـرب حداكثر و حداقل سـرانه كـاربرى ci در جمعيست كـل منطقه موردمطالعه به دست مىى آيـد. Ai نيـز مجمــوع مساحت يلاكهاى دربر گيرنده كاربرى ${ }^{\prime}$ است.

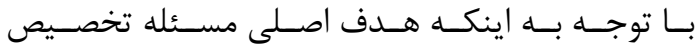

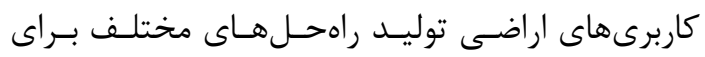
برنامهريزى كاربرىهاى اراضى است، اسـتفاده از دانسش إنى نظـارتى در قالـب قيـود مختلــف مــى توانـد از توليـد جوابهاى غيرواقعى جلوگيرى نمايسـ [ب]. بــراى مثـال هر كاربرى مىبايست به معبر متناسب با عملكـرد خـود

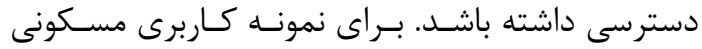
نبايد بهصورت مستقيمم بـه شـريانهـاى اصـلى شـهرى

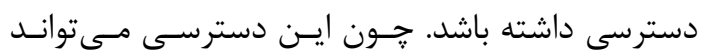

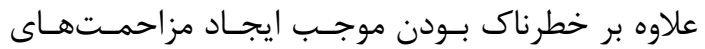

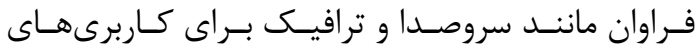
مسكونى شود. قيود زير مىتواند در توليـد جـوابهــاى

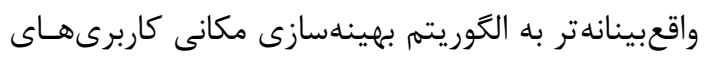
شهرى كمك نمايد [سF]. 


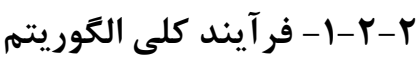

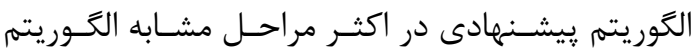

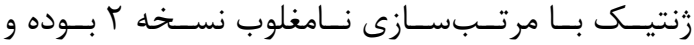

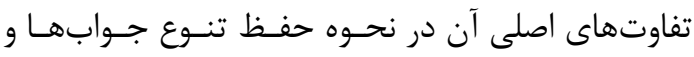

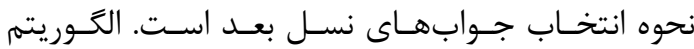

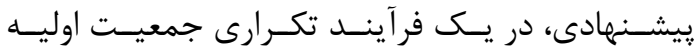
توليد شده را بهينهسازى نموده و با حفظ تنوع جوابها

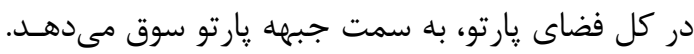

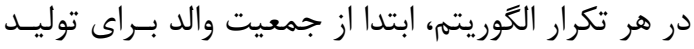
جمعيت فرزند با بهكار كيرى عملكرهاى تقاطع و جهش آنش

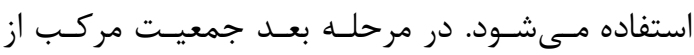
جمعيت والد و فرزند توسط اهداف تعريف شده ارزيـابى دردي

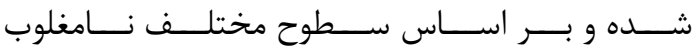
مرتب مىشوند. مرتبسازى نامغلوب همانــــد الحَـوريته

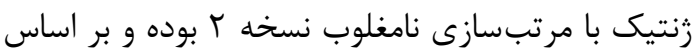

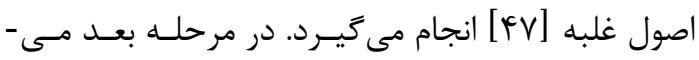

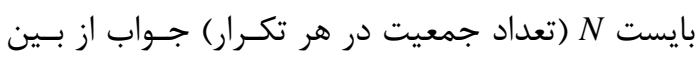

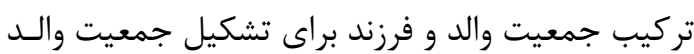

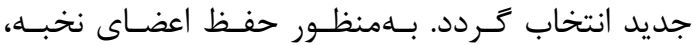
جمعيت والد جديد مىبايست بر اساس سطوح مختلـف

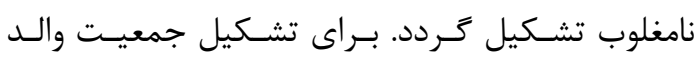
جديد، الكَوريتم از سطح يكى نامغلوب شروع به انتخــاب

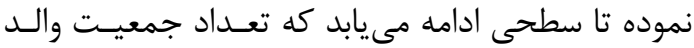

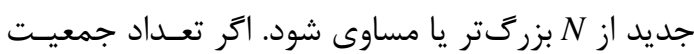
والد دقيقاً برابر N شود نيازى به انجام عمليـات ديخــرى نبوده و تكرار بعدى شروع مىشود. امـا در صـورتى كـهـ

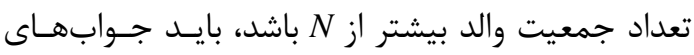

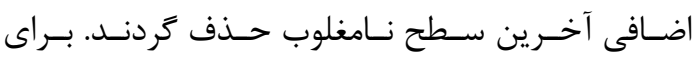
اين منظور با تشكيل شبكه در فضاى يارتو و اختصـاص هر جواب به يك سلول از شبكه، تعداد همسايههاى هـــــ

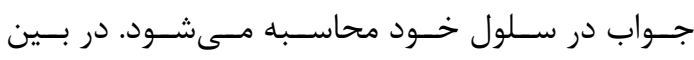

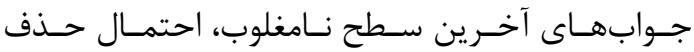
جوابهايى كه داراى همسايكان بيشترى هستند، بالاتر

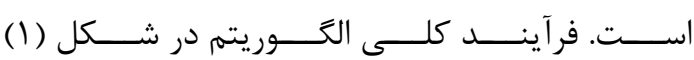

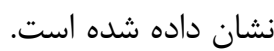

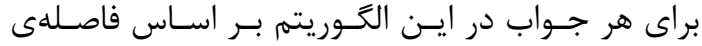

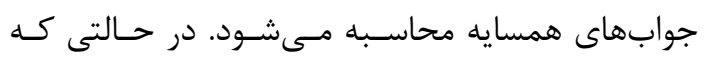

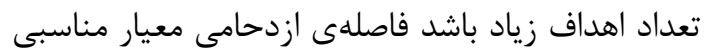

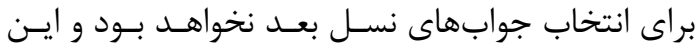

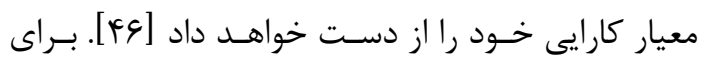

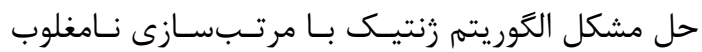

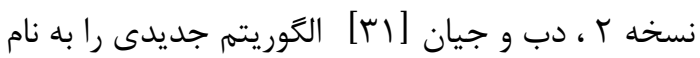
الكَوريتم زنتيك با مرتبسازى نـامغلوب نسـخه بَ ارائسه

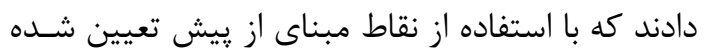
در فضاى يارتو و خوشهبندى جوابهــا بـر اسـاس ايـن

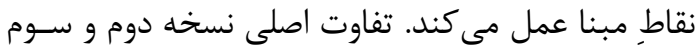

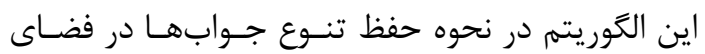

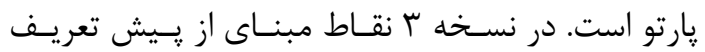
شده وظيفه حفظ تنوع را بر عهده دارند. ايـن الخــوريتهم

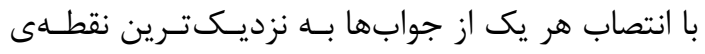

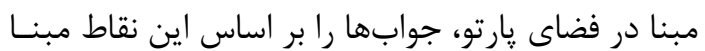

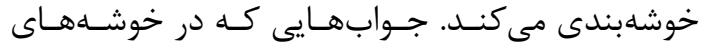
كوجكتر قرار كرفتهاند شانس بيشترى را براى راهيـابى

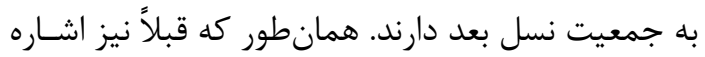
شد، با توجه به عدم ارائه كـدهاى منبــع ايــن الخــوريته توسط نويسند

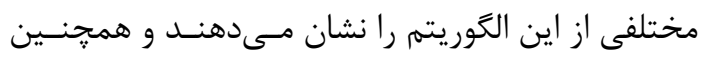

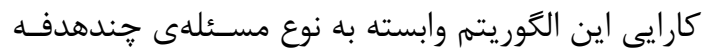

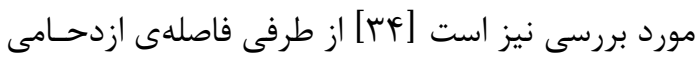

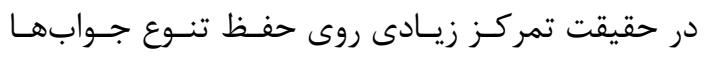

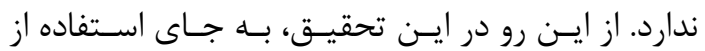
فاصلهى ازدحامى و نقاط مبنا براى حفظ تنوع جوابهـيـا در فضاى يارتو، از يك شـبكه اسـتفاده كرديــده اسـت.

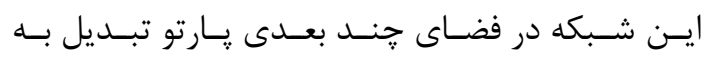

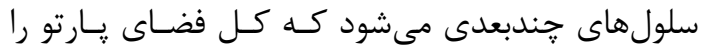

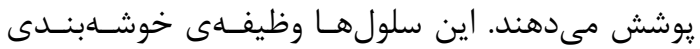

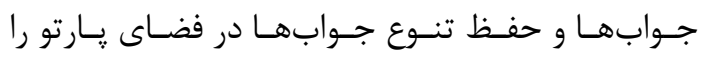

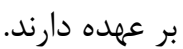




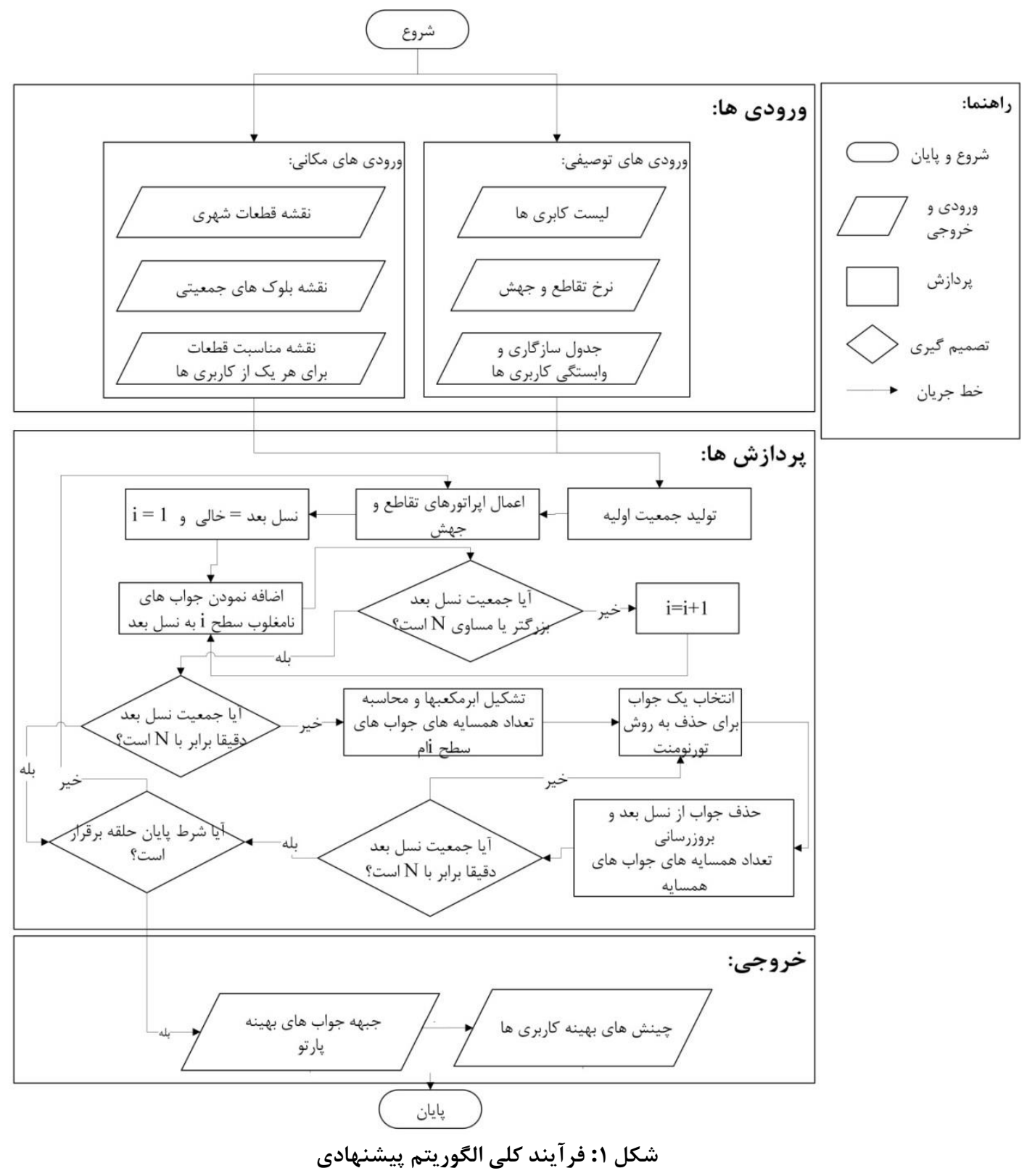

براى حذف جوابهاى اضافى در آخرين سطح نامغلوب،

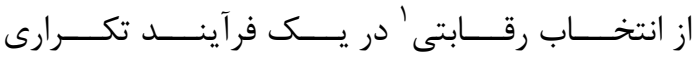
استفاده شده است. در اين انتخاب، از بين ه جوابى كـهـ

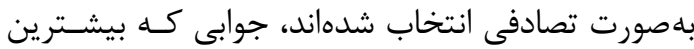

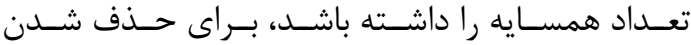

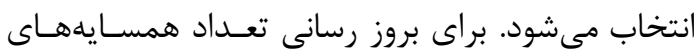

الكوريتم پِيشنهادى براى محاسبهى تعداد همسايههـاى

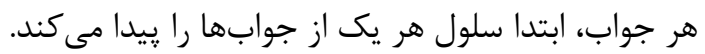

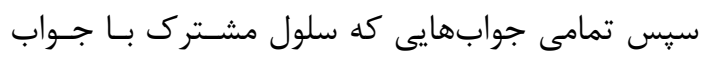
مورد بررسى دارد را بهعنوان همسايههاى جـواب مـورد بر بى در نظر مى تيرد.

\footnotetext{
${ }^{1}$ Tournoment Selection
} 
دارد. در اكثــر تحقيقــات مربـوط بــه تخصـيص بهينــه

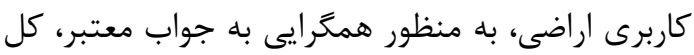

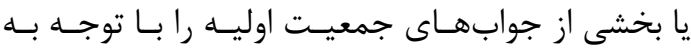
وضعيت موجود كاربرىها در منطقه موردمطالعه توليـد بـ نـ

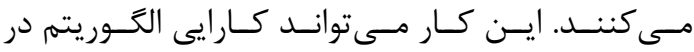

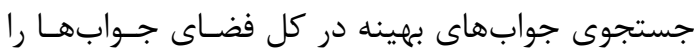

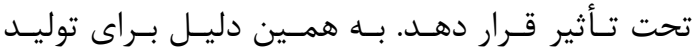
جمعيت اوليه مستقل از وضـعيت موجـود، در الحَـوريتهم ييشنهادى، جيدمان كاربرى اراضى بهعنوان جوابهـاى

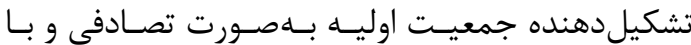
در نظـر حـرفتن قيـود تعريـف شــده توليـد مسى شـوند.

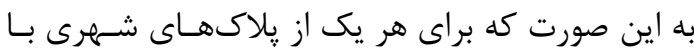

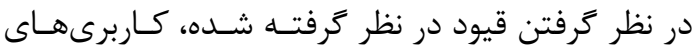

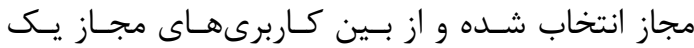
كاربرى به صورت تصادفى به يلاكى موردنظر اختصـاص

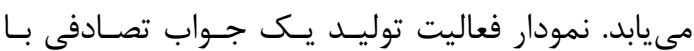
در نظر گرفتن قيود در شكل (r) نشان داده شده است.
جوابهاى همسايه نيز مىبايسـت يـك واحـد از تعـداد همسايdها كم گردد.

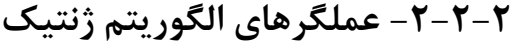

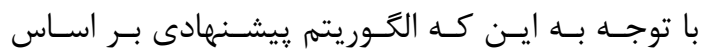

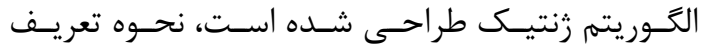
كروموزومها، زنها و همجنين عملكَرهاى اين الحــوريتم

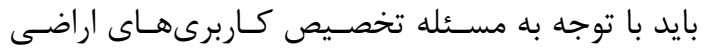

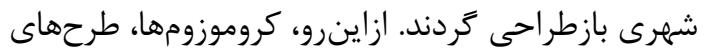
كاربرى اراضى و زنهاى هر كروموزوم، نوع كاربرى هـر

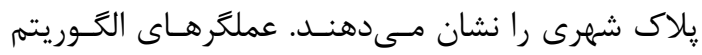
زنتيك نيز شامل توليد جمعيت اوليه، تقـاطع و جهـش رل است. در ادامه نحــوه عملكـرد هريـك از ايـن عملگرهــا توضيح داده مىشود. r-r-r-1- توليد جمعيت اوليه توليد جمعيت اوليه در الكوريتمههـاى تكـاملى، يكـى از

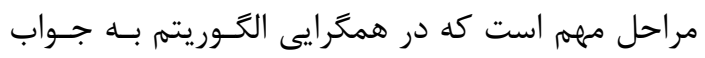
بهينه كلى و همجين سرعت همخرايى تأثير بـه سـزايى

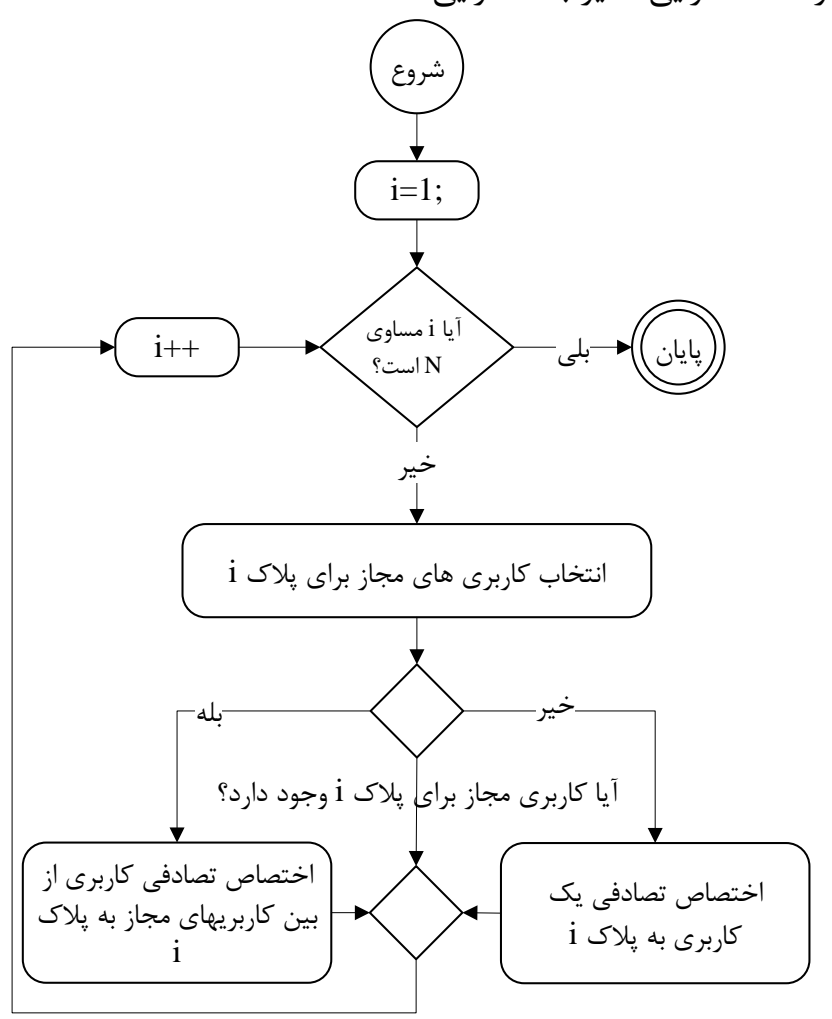

شكل r: نمودار فعاليت توليد يك جواب تصادفى با در نظر گرفتن قيود تعريفشده. 
منطقه مسئله مديريت كاربرىهـاى شـهرى را يِيجيـده r-Y-r-r-r-r-r مىسازد. در منطقه موردمطالعه لايه يلاكىهـاى شهرى مهرى

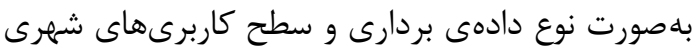
در ^ر كلاس كاربرى با توجه به سه حد آستانه محلـى، ناحيهاى و منطقهاى تعريف شده است. تعداد يلاكهاى

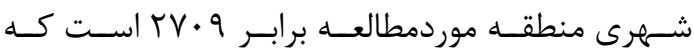

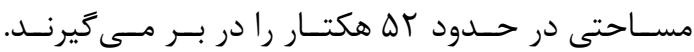

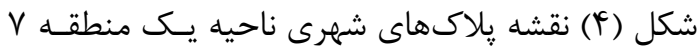

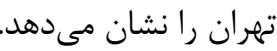
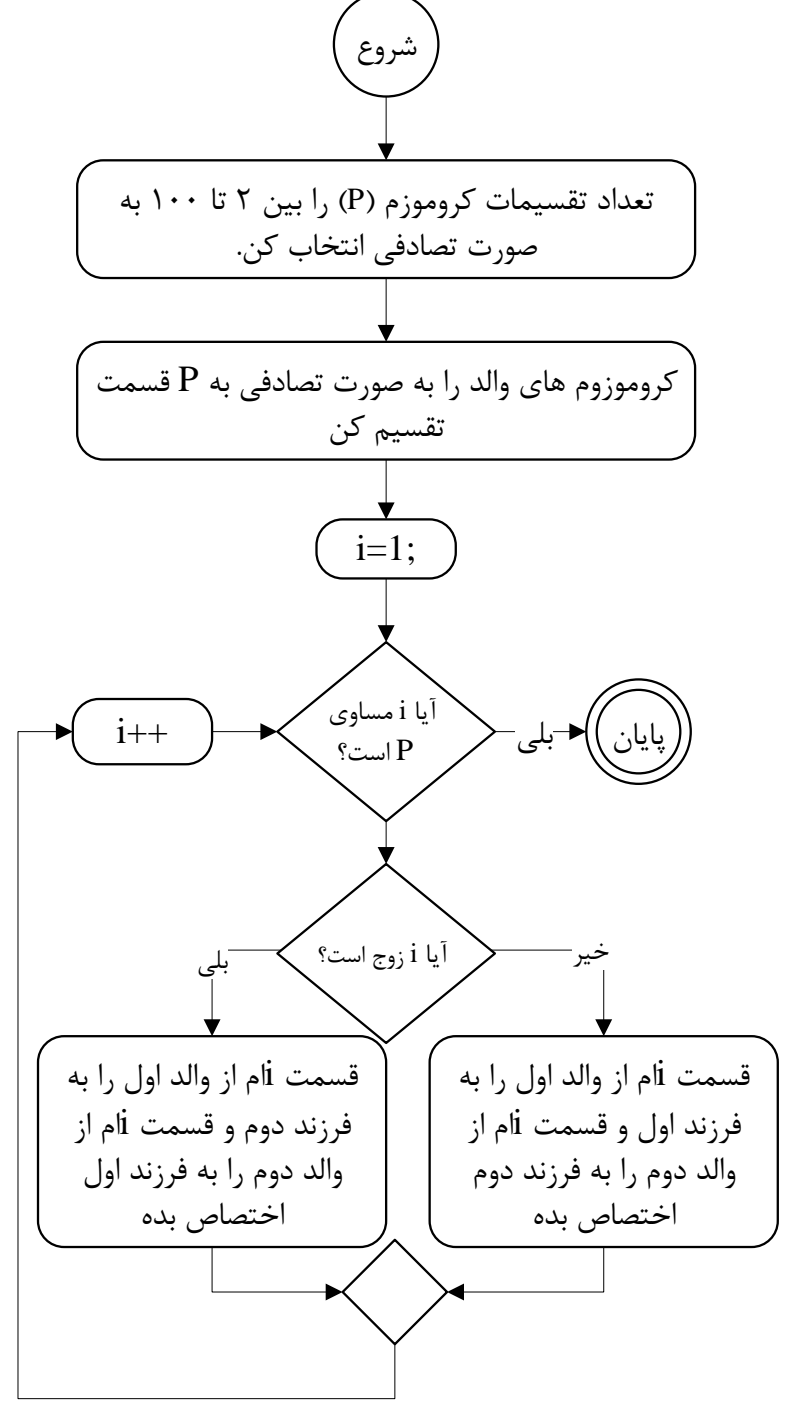

شكل ب: نمودار فعاليت توليد دو جواب فرزند از طريق عملكر تقاطع

در الكوريتم زنتيكى از عملغر تقـاطع بــراى جسـتجو در

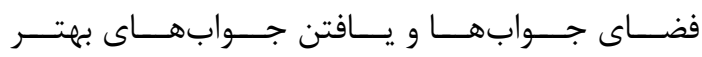

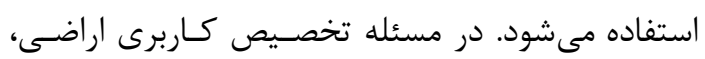

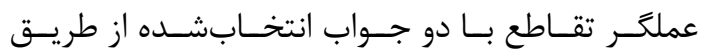
جستجوى رقابتى '، دو جواب بـراى نسـل بعـدى توليـد

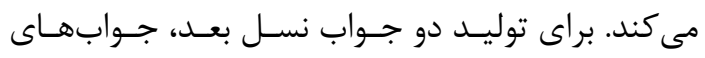

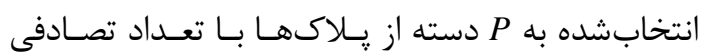

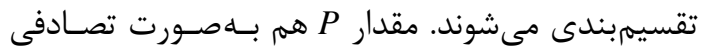

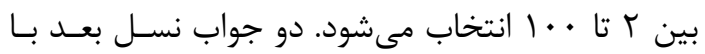

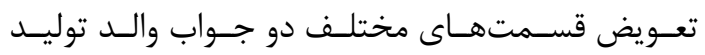
مىشوند. شكل (r) فرآيند تقاطع را بـهـــورت نمـودار

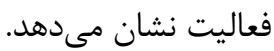
r-r-r-r يكى ديخر از عملكَرهاى الكوريتم زنتيك، جهـش اسـت كه براى ايجاد تنوع بيشتر در جـوابهــا و جلـوخيرى از گيركردن در جوابهاى بهينهى محلى طراحى زرديـده

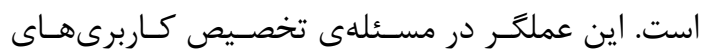

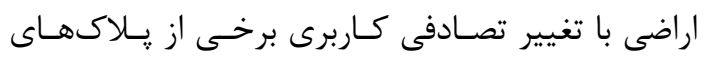

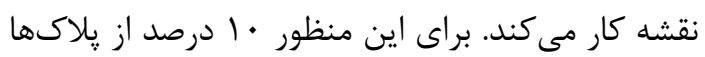
بهصورت تصادفى انتخاب شده و كاربرى آنها بهصـورت تصادفى به يـك كـاربرى مجــاز ديخــر تغييـر مـى كنـد.

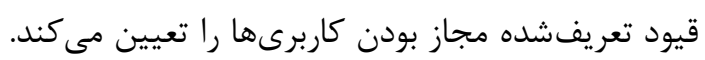

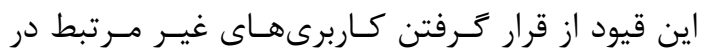

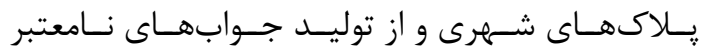
جلو گيرى مى كنند.

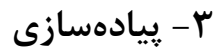

دادههاى كاربرى اراضى ناحيه يك منطقه V تهران براى

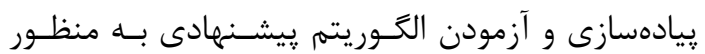
بهينهسازى كاربرىهاى شهرى بكار گرفته شده است. از نقاط قابل توجه در اين منطقه، وجود كاربرىهاى متنوع

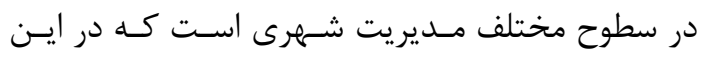

${ }^{1}$ Tournament Search 

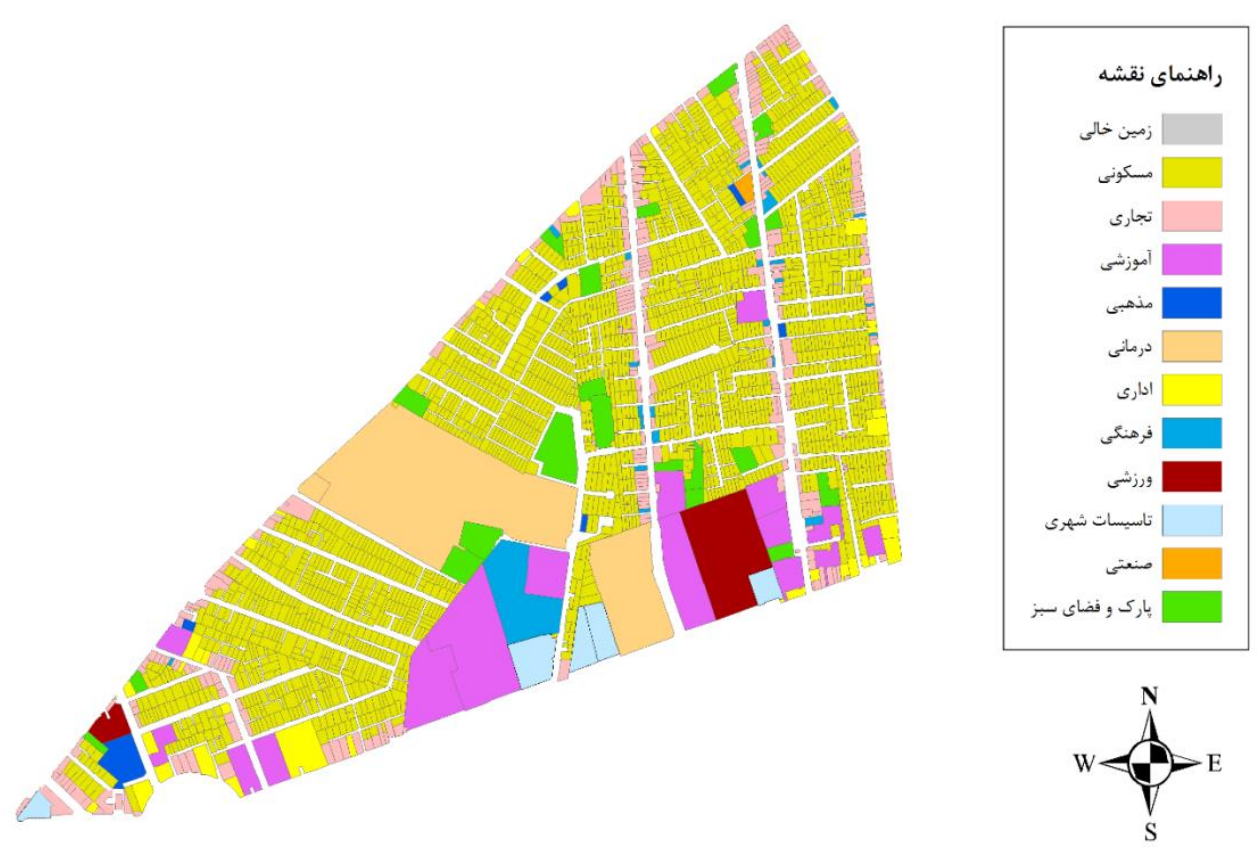

شكل F: نقشهى كاربرىهاى منطقه موردمطالعه

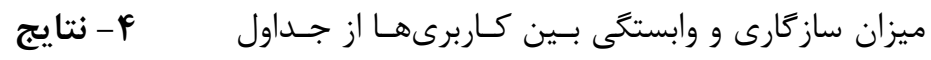

بــراى تعيـين קارامترهــاى بهينـهســازى شـامل تعـداد

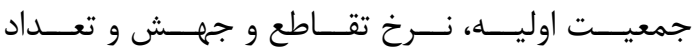

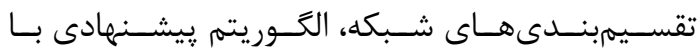
يارامترهاى مختلف اجرا شد و بهتـرين مقـادير انتخـاب

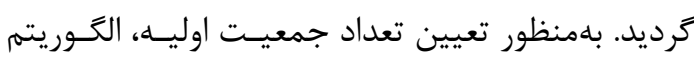
ييشنهادى با مقادير جمعيت اوليه مختلف و تعداد تكرار

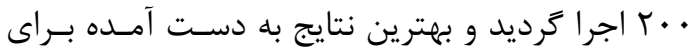
اهداف مختلف، براى انتخاب جمعيت اوليه مناسب مورد بررسى قرار گرفت. شكل (ه) تغييـرات بهتـرين مقـادير اهداف اول تا جهارم را نسبت به افزايش مقدار جمعيـت اوليه نشان مى دهد. با توجه بـهـ اينكـهـ هـــف يــنجم در

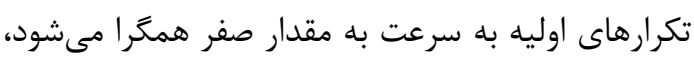

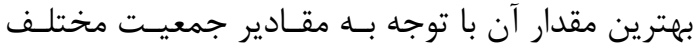
همواره برابر صفر بوده و درنتيجه از نشـان دادن شـكل

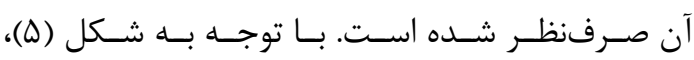

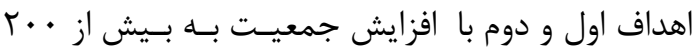
تغييرات زيادى در بهترين مقادير خود نشان نمى دهند.

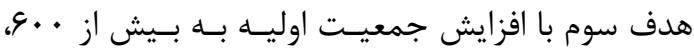

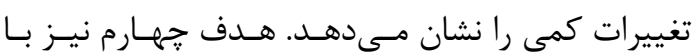

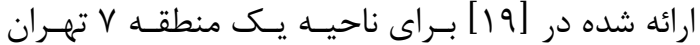
استخراج شده است. سرانه كاربرىهاى شـهرى در ايسن

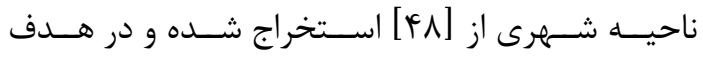

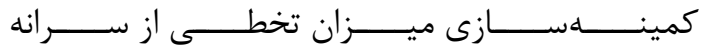
به كار گرفتته شده است. ميزان تراكم مسكونى بـا توجـهـ

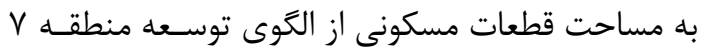

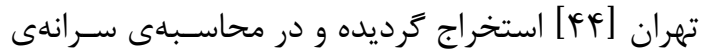
كاربرىهاى مسكونى اعمال گردديـده اسـت. نــوع معـابر

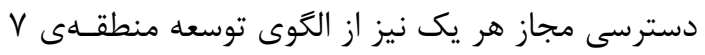

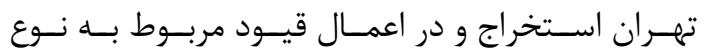
دسترسى كاربرىها استفاده شده است. ميزان حـداقل و حداكثر مساحت مجاز يلاكى شـهرى بـراى هــر يـك از

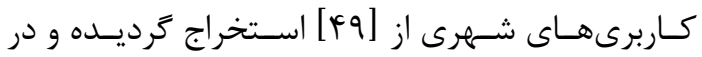

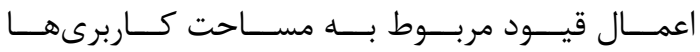

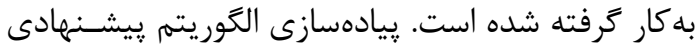
در محيط ويثوال استاديو • ا • إ و بـا اسـتفاده از زبـان

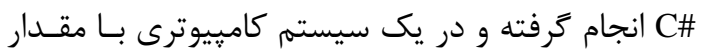

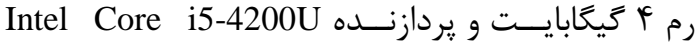
اجرا زرديده است. 
به يك ثبات نسبى برسند. همجنين با توجه به اجراهاى

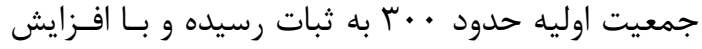

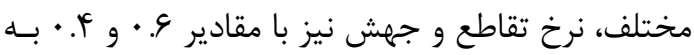
جمعيت اوليه تغيير محسوسـى در بهتـرين مقـدار ايسن نتايج بهترى منجر مىشوند. هدف نيز رخ نداده است. درنتيجه، مقدار جمعيت اوليـه

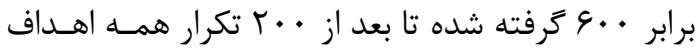
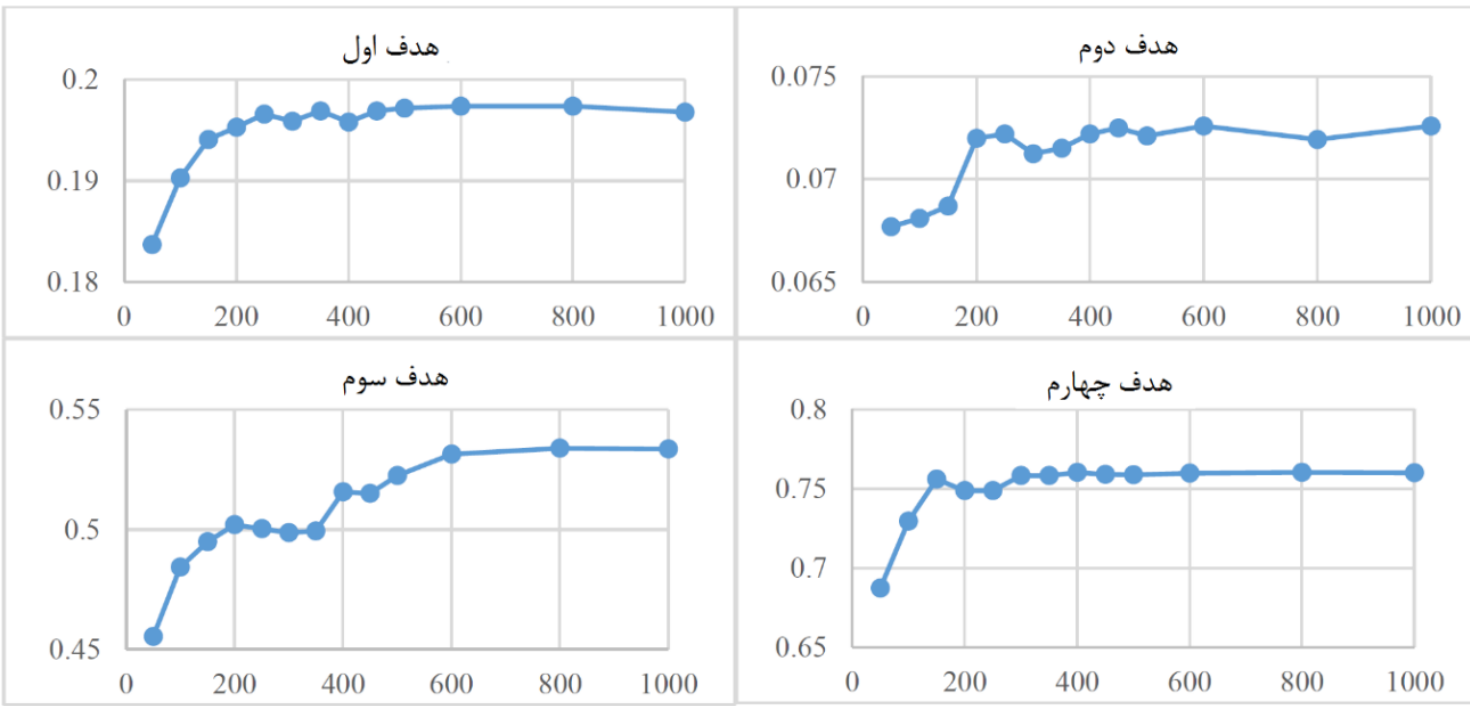

شكل ه: تغييرات مقدار اهداف با توجه به تعداد جمعيت اوليه متفاوت

اهداف خيلى زياد شده و اكثــ ايـن سـلولهـا خـالى از يكى از يارامترهاى مهـم در نحـوه توزيــع جـوابهــا در

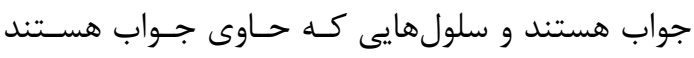

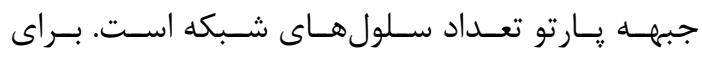

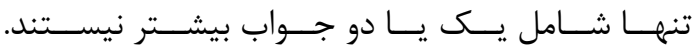
تعيين اين يارامتر، با ثابت در نظــر حـرفتن يارامترهـاى در اين صورت تعداد همسايههاى هر جواب به صـفر يـاـ

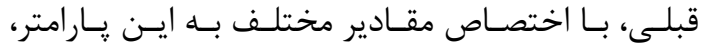

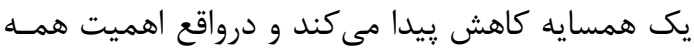

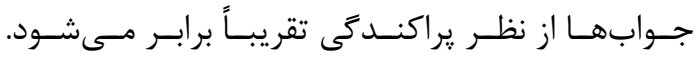

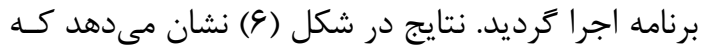

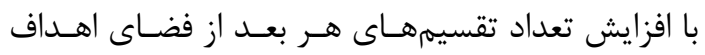
معيار קراكندكى جوابهاى نهايى بهببود يِيـدا مسى كنـد. تصادفى جوابهاى نسل بعـد را انتخــاب كنــد و ميـزان

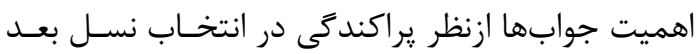

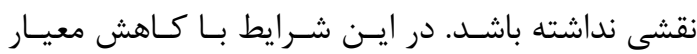

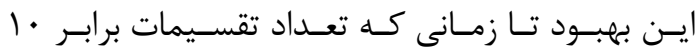

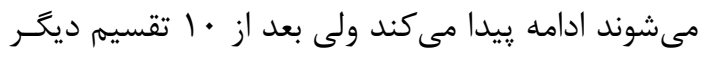
يراكندكى در جوابهاى نهايى مواجه هستيه. درنتيجـهـ

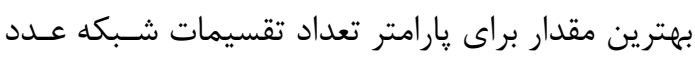

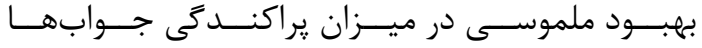

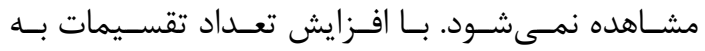

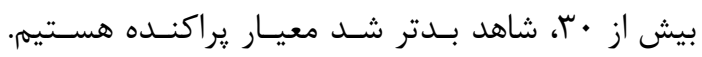
• إمىتواند باشد.

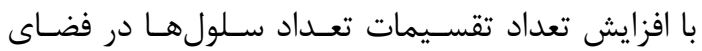




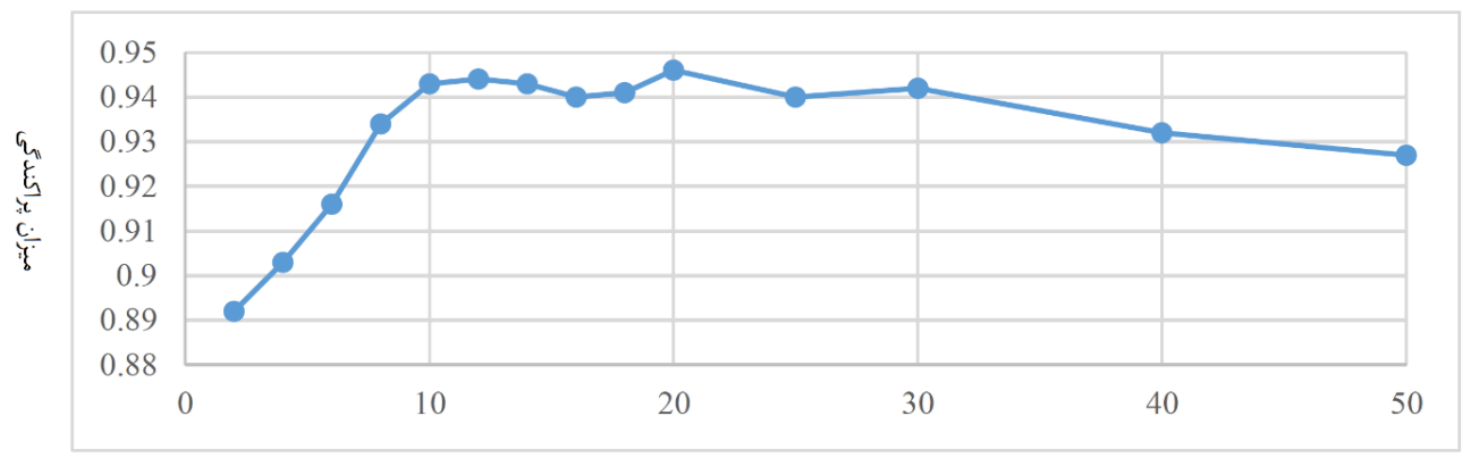

تعداد تقسيمات در فضاى اهداف

شكل و: نمودار معيار يراكندكى نسبت به تعداد تقسيمبندىهاى شبكه در فضاى اهداف.

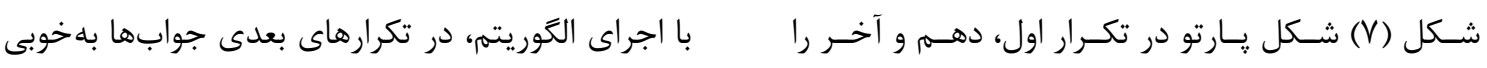

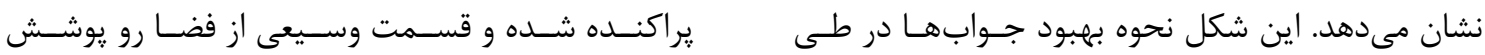

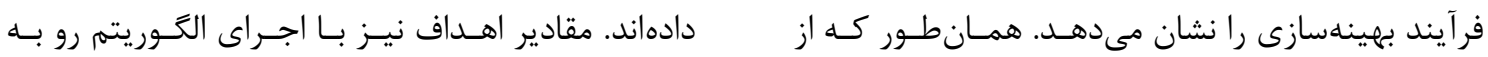

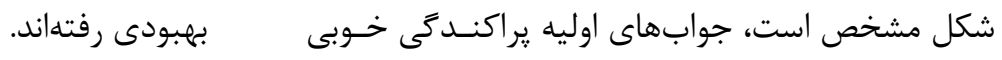
در فضاى اهداف ندارند و در يك قسمت متمركزشدهاند.

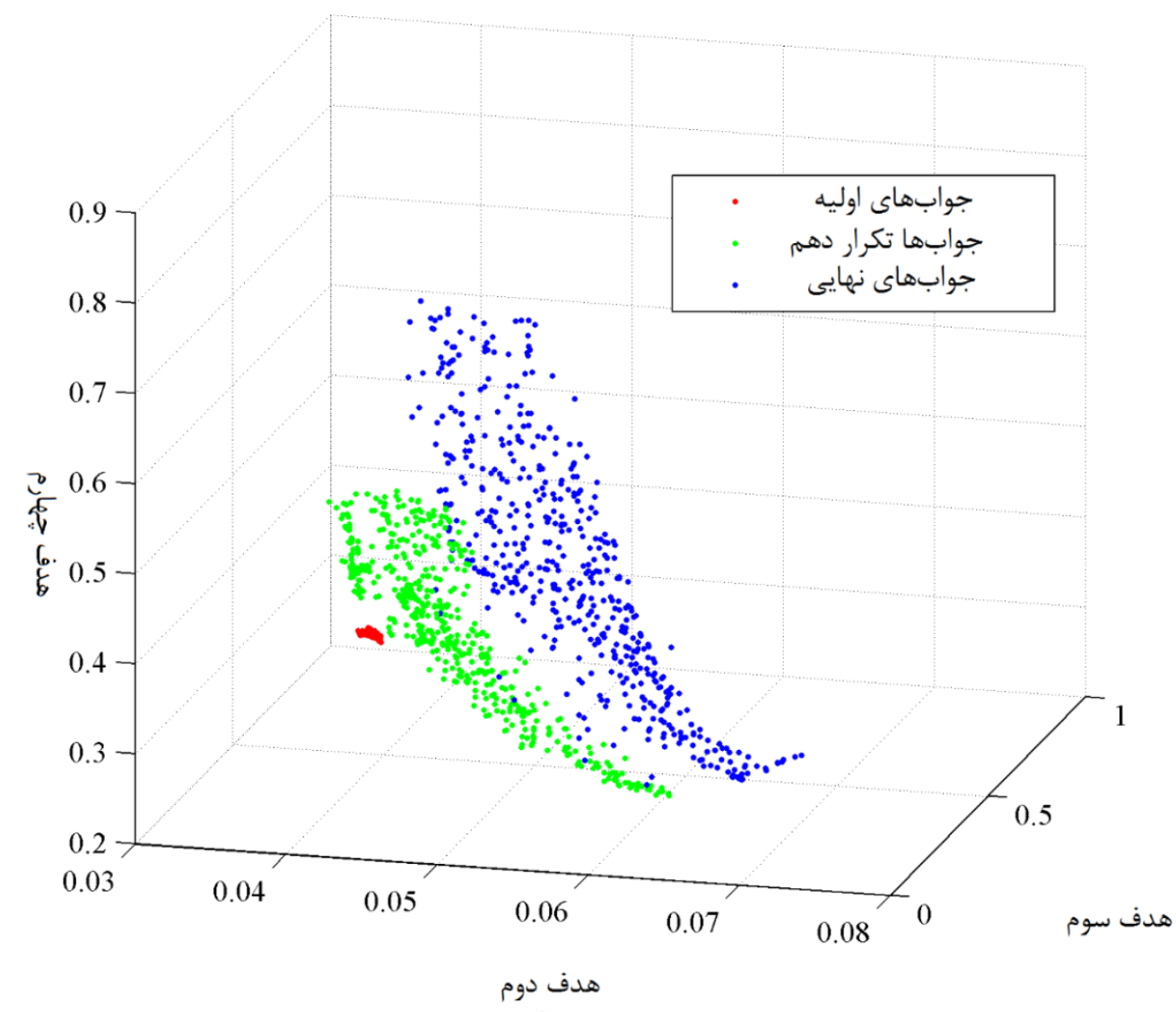

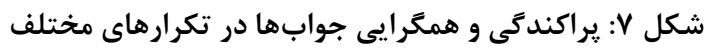


اختصاص مى دهند. دليل آن نيز مىتوانـد ماهيـت تـابع

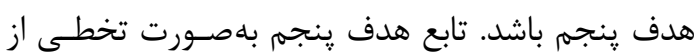
حداقل و حداكثر سرانه كاربرىها محاسبه مىشود و بــهـ همين دليل جوابهاى متفاوتى مىتواند حداقل ميـزان

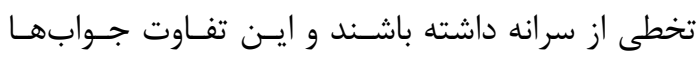

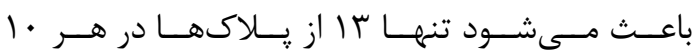

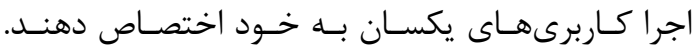

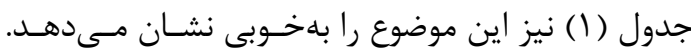

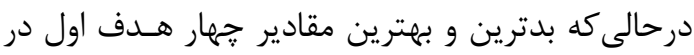

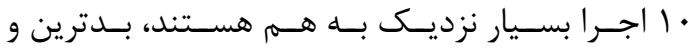
بهترين مقادير هدف ينجم در · ل اجرا تغييرات زيـادى هني

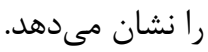
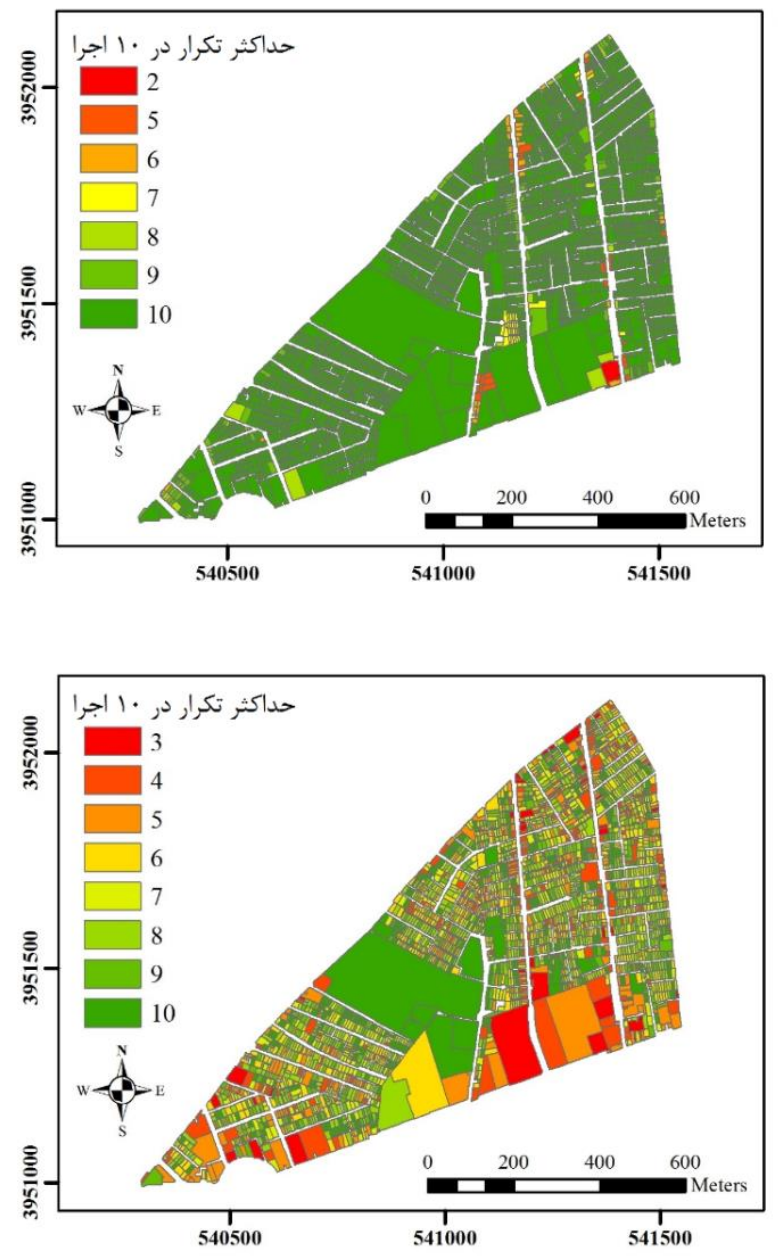

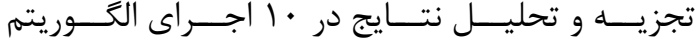

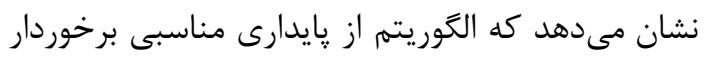
است و در اجراهاى مختلف به نتايج مشابهى مسىرسـد.

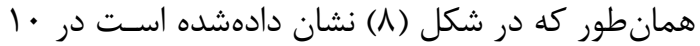

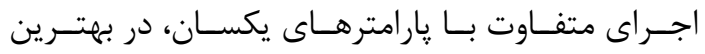

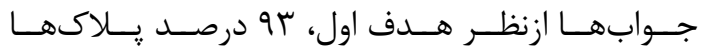

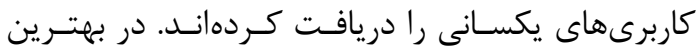

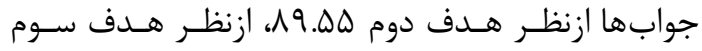

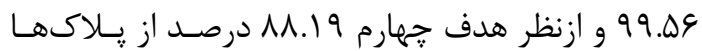

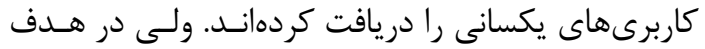

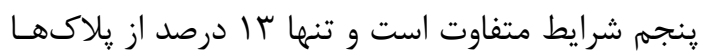

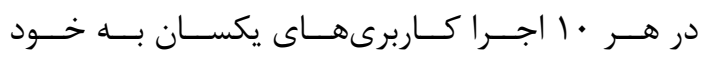

$$
\text { درصد يֶاكها با حداكثر تكرار كاربرى براى هدف اول }
$$

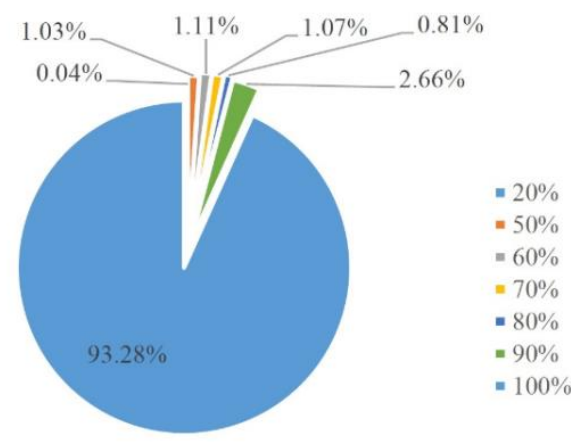

درصد يلاكها با حداكثر تكرار كاربرى براى هدف هنجم
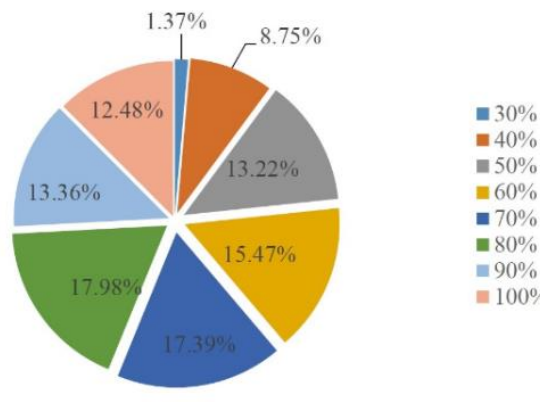

شكل 1: ميزان هميوشانى جوابها در اجراهاى متفاوت 
جدول ا: بدترين و بهترين مقادير اهداف مختلف در اجراهاى متفاوت

\begin{tabular}{|r|r|r|r|r|r|r|r|r|r|r|r|}
\hline & \multicolumn{2}{|r|}{ objective 1 } & \multicolumn{2}{|r|}{ objective 2 } & \multicolumn{2}{|r|}{ objective 3 } & \multicolumn{2}{|r|}{ objective 4 } & \multicolumn{2}{|r|}{ objective 5 } \\
\hline & Worst & Best & Worst & Best & Worst & Best & Worst & Best & Worst & Best \\
\hline Run1 & 0.1038 & 0.1969 & 0.0388 & 0.0727 & 0.1417 & 0.5337 & 0.2505 & 0.7599 & 9.4177 & 0 \\
\hline Run2 & 0.1033 & 0.1971 & 0.0402 & 0.0712 & 0.1483 & 0.5337 & 0.2488 & 0.76 & 9.4039 & 0 \\
\hline Run3 & 0.1036 & 0.1974 & 0.0387 & 0.0727 & 0.1418 & 0.5341 & 0.25 & 0.7601 & 10.0576 & 0 \\
\hline Run4 & 0.1037 & 0.1973 & 0.0399 & 0.0727 & 0.1414 & 0.5337 & 0.2535 & 0.7601 & 9.9615 & 0 \\
\hline Run5 & 0.1035 & 0.1973 & 0.0391 & 0.0727 & 0.1425 & 0.5337 & 0.2578 & 0.7602 & 9.621 & 0 \\
\hline Run6 & 0.1037 & 0.1974 & 0.0396 & 0.0727 & 0.1417 & 0.534 & 0.253 & 0.7602 & 10.3944 & 0 \\
\hline Run7 & 0.1032 & 0.1974 & 0.0419 & 0.0726 & 0.1407 & 0.534 & 0.2532 & 0.7599 & 9.4346 & 0 \\
\hline Run8 & 0.1032 & 0.1971 & 0.0376 & 0.0724 & 0.1451 & 0.5341 & 0.2467 & 0.7599 & 10.2337 & 0 \\
\hline Run9 & 0.1044 & 0.1974 & 0.041 & 0.0727 & 0.1414 & 0.5341 & 0.244 & 0.7599 & 9.386 & 0 \\
\hline Run10 & 0.104 & 0.1972 & 0.0393 & 0.0726 & 0.1414 & 0.5337 & 0.2536 & 0.76 & 9.3485 & 0 \\
\hline
\end{tabular}

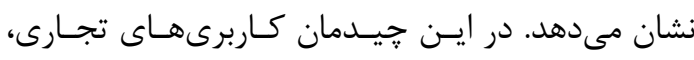

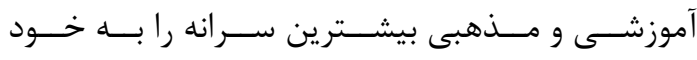

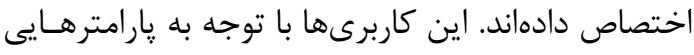

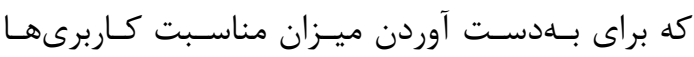

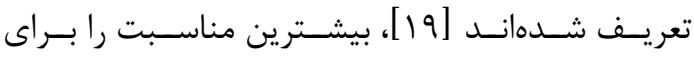

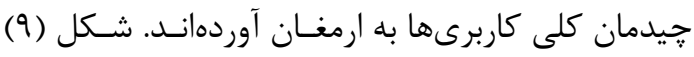

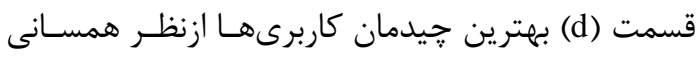
كاربرى هاى مجاور را نشان مى دهد. كاربرى هان كاى همسان

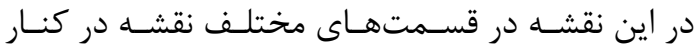

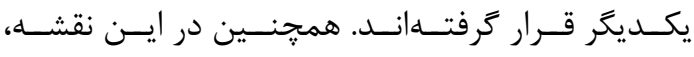

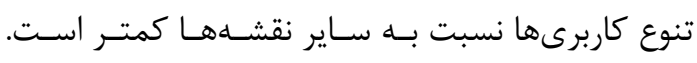

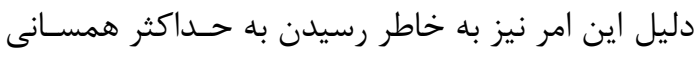

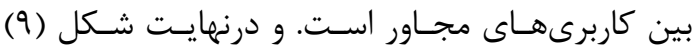

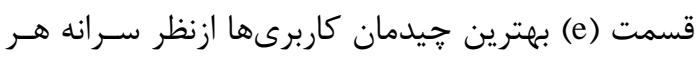

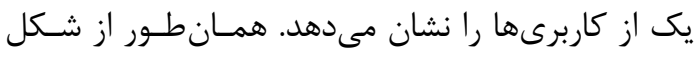

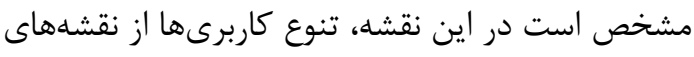

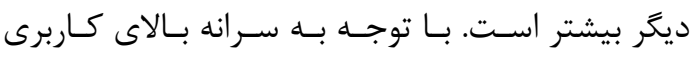

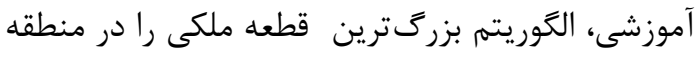

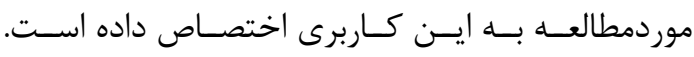

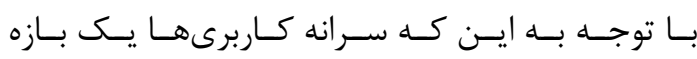

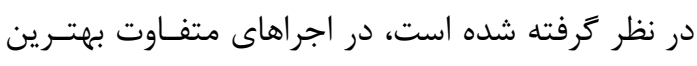

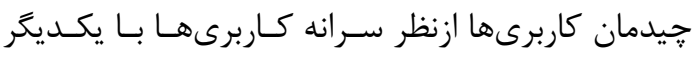

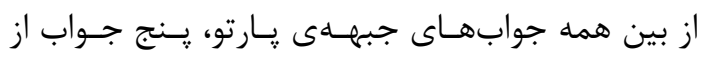

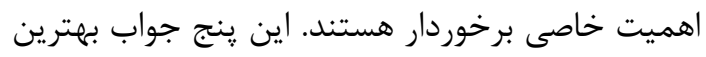

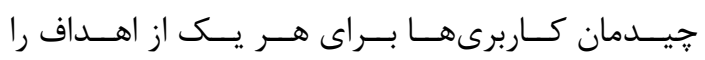

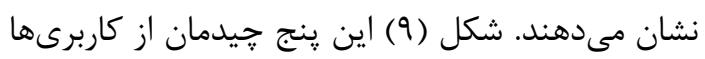

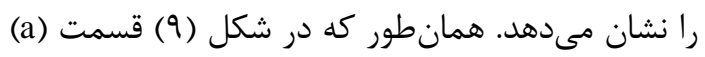

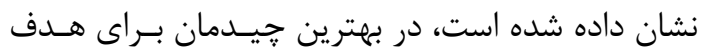

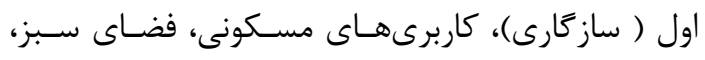

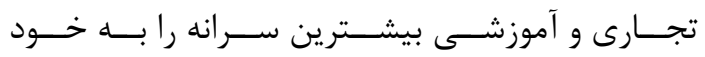

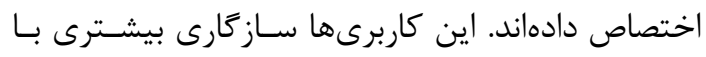

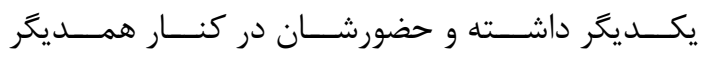

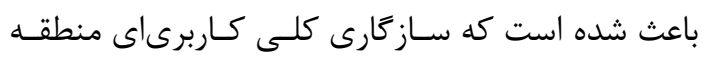

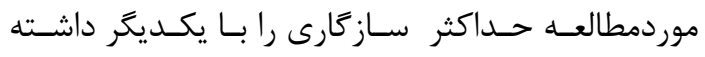

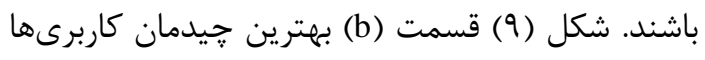

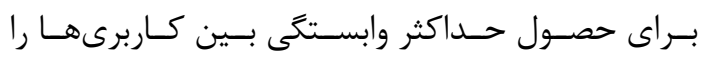

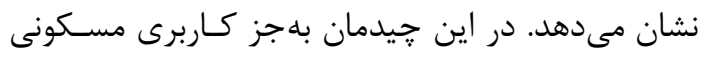

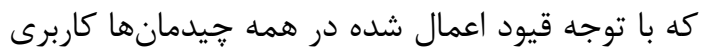
غالب محسوب مىشود، كاربرى هاى ورزشى و تأسيسات

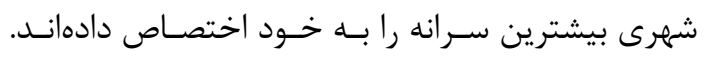

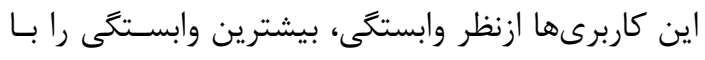

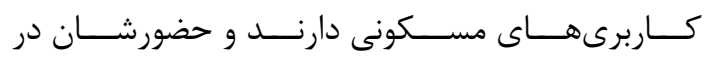

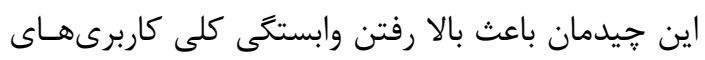

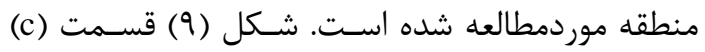

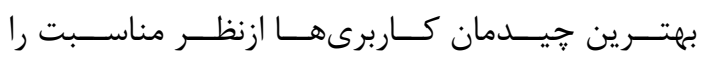


ار ائهى يك الكَوريتم يُندهدفه سلولى براى تخصيص ...

جمشيد مالكى، فرشاد حكيميور، زهره معصومى

اين تفاوتها را بلهوبى نشان مىدهد.

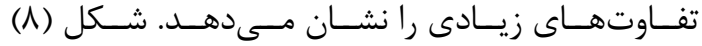
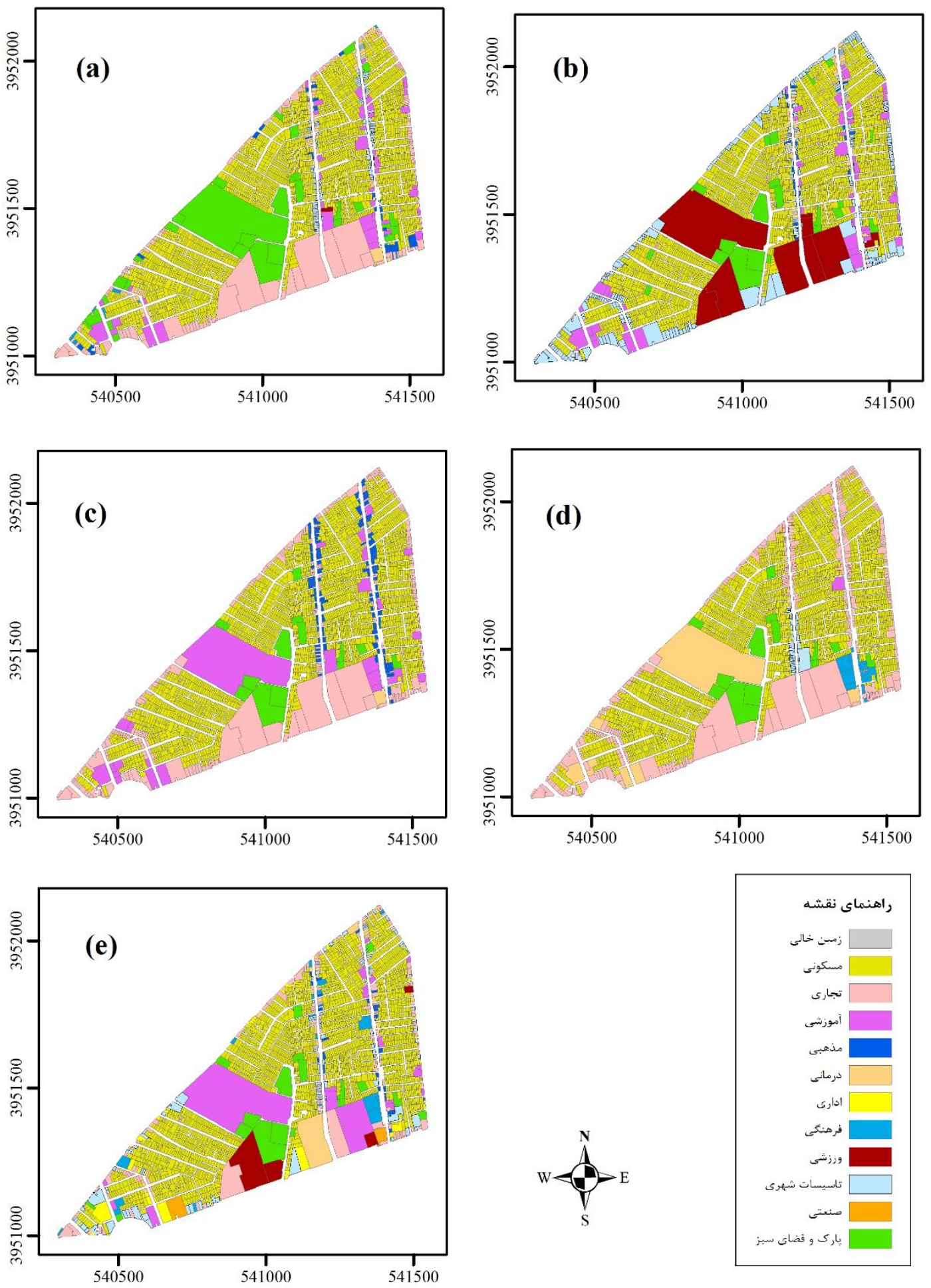

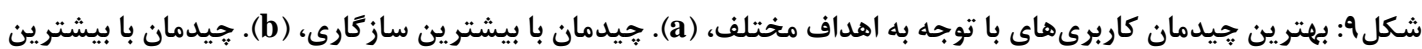

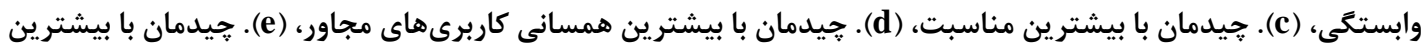
تأمين سرانه 
هدف كلى (T) زير استفاده شده است.

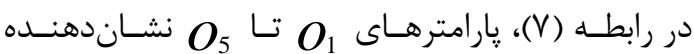

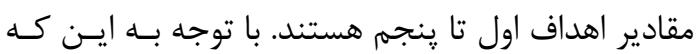

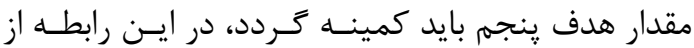
مقدار كل كسر گرديده است. پارامترهاى W. نشاندهنده وزن هر يك از اهداف هستند. بـراى توليـد

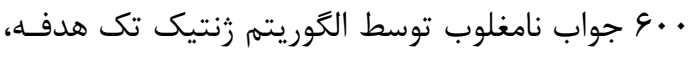
بايد اوزان مختلفى استفاده گردد. براى توليـد تصـادفى اين اوزان بهصورتى كه مجموع آنها برابر يك شود يك مانى بردار در فضاى اوزان بهصورت تصـادف انتخــاب شـده و

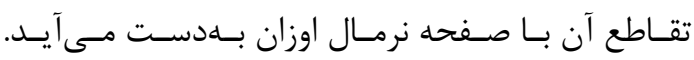

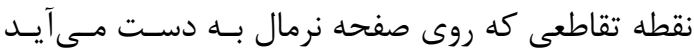
ينج وزن تصادفى خواهد بود كه مجموعشان برابـر يـك روك

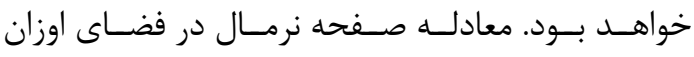
بهصورت رابطه (1) است.

$$
\text { ه- ارزيابى نتايج }
$$

به منظور ارزيابى نتايج حاصل از بكاركيرى شبكه بــراى

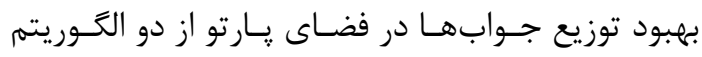

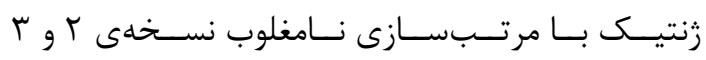
بدون در نظر كرفتن شبكه در (NSGAIII و

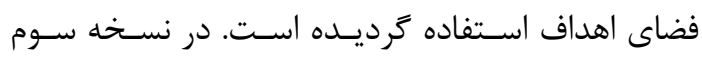

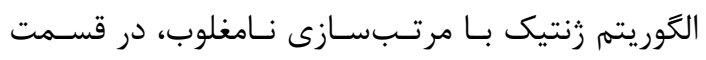

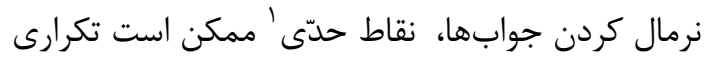

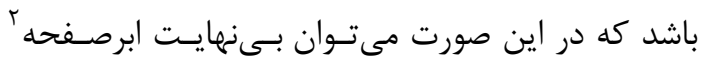

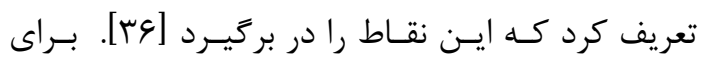

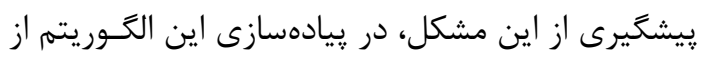

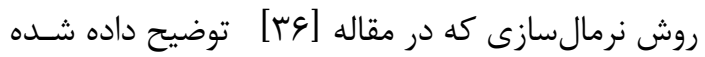
است استفاده كرديده است.

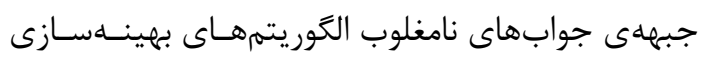
جندهدفـه را مسىـــوان از دو منظــر همكرايسى و مـورد

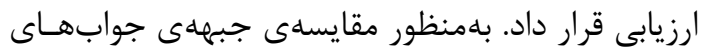

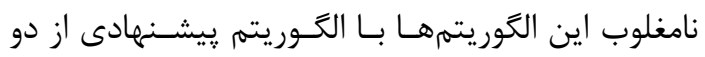

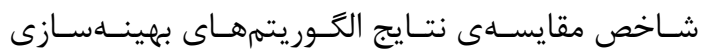
קندهدفه استفاده كرديده است. اين دو شاخص شـامل

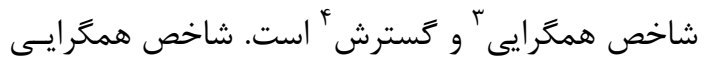

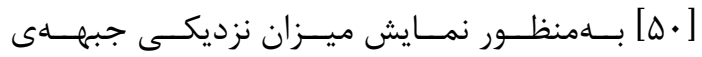

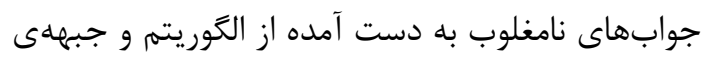

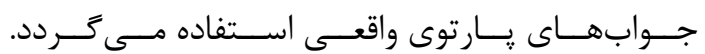

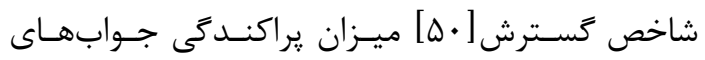
نامغلوب را نشان مىدهد. براى محاسبه هر دو شـاخص معرفىشده، جبهلى جوابهاى زيـارتو واقعى موردنيـاز

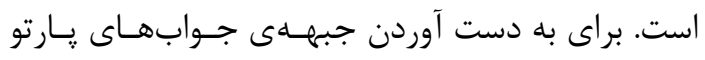
مستقل بهمنظور ارزيابى نتايج سه الكوريتم يادشـده، از از

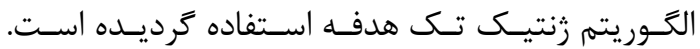
الكوريتم زنتيك تك هدف براى حداكثرسازى تابع

${ }^{1}$ Extreme Points

${ }^{2}$ Hyperplane

${ }^{3}$ Convergence Metric

${ }^{4}$ Spread Metric 


$$
T=\mathcal{W}_{1} \times \boldsymbol{O}_{1}+\mathcal{W}_{2} \times \boldsymbol{O}_{2}+\mathcal{W}_{3} \times \boldsymbol{O}_{3}+\boldsymbol{W}_{4} \times \boldsymbol{O}_{4}-\mathcal{W}_{5} \times \boldsymbol{O}_{5}
$$

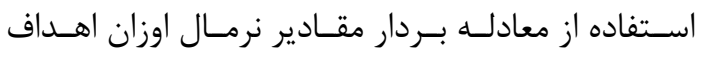

$$
\begin{aligned}
& W_{1}+W_{2}+W_{3}+W_{4}+W_{5}=1 \quad \text { رابطه (^) } \\
& \text { و معادله بردارى تصادفى در فضاى وزن ها بهصورت زيـر }
\end{aligned}
$$

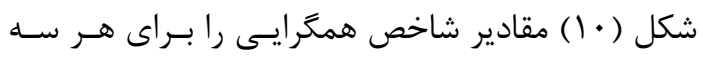
قابلبيان است:

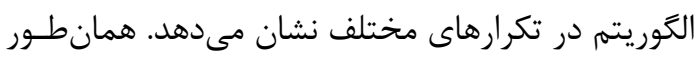

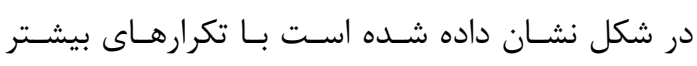

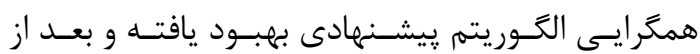

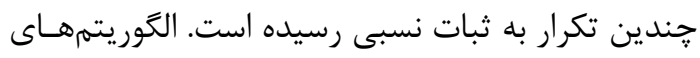

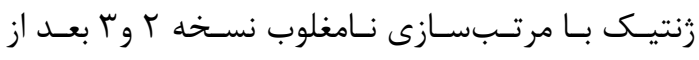

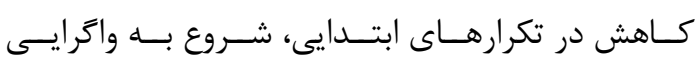

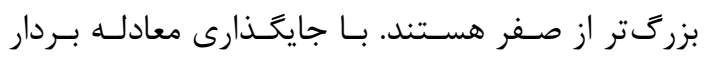

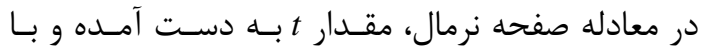

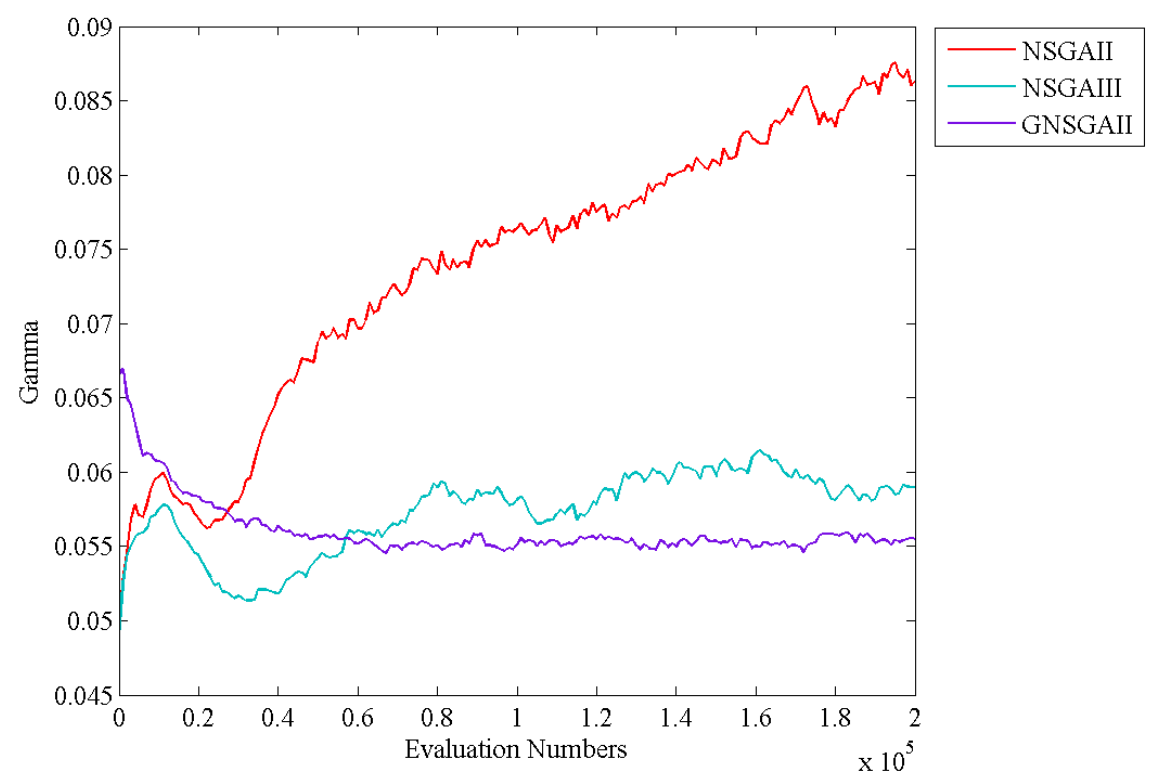

شكل •ا: شاخص همكَرايى سه الكَور يتم مورد ارز يابى

افزايش يافته و رو به بدتر شدن رفته است. همـانطـور

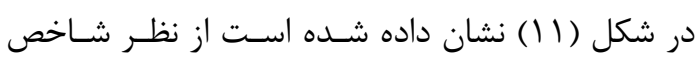

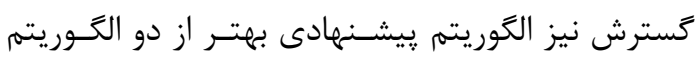

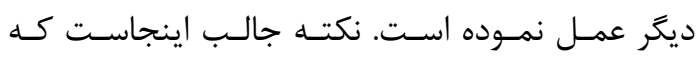

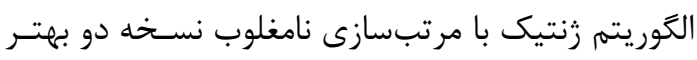
از نسخه سوم عمل نموده است.

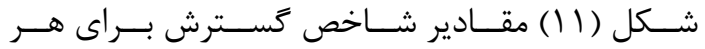
سه الكَوريتم در تكرارهاى مختلف نشان مى دهد. مقادير

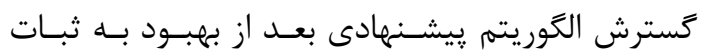

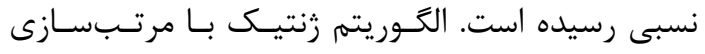

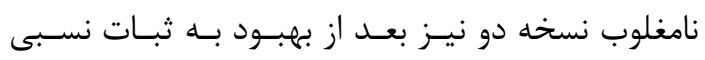

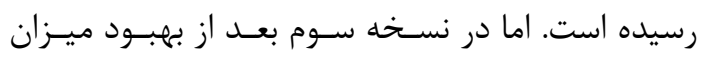

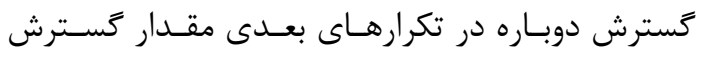



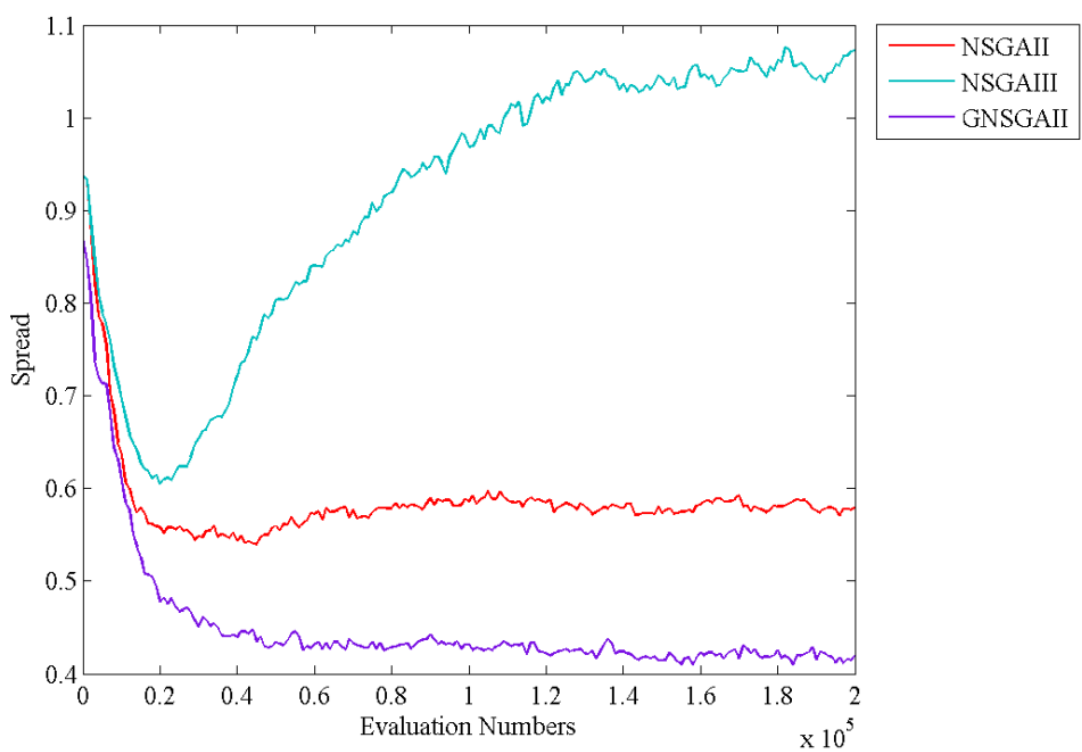

شكل||( شاخص گَسترش سه الكَوريتم مورد ارزيابى

و تشكيل اين شبكه تنها با دو نقطه در فضـاى اهـداف، استفاده از شبكه نسبت به محاسبه فاصله ازدحامى در كارامـدتر اسـت. سـلولهـــــGAII

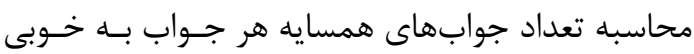
مى تواننـد توزيـع جــوابهــا در فضـاى يـارتو را بهبـود بخشند. با توجه به ماهيت مسئله تخصيص كـاربرىهـا،

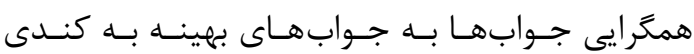
صورت گرفته و نياز به آزمون وخطاهاى زيادى است تـا

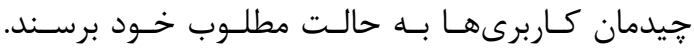
از اينرو در اين تحقيق يك عملكر جديد بـراى تقـاطع

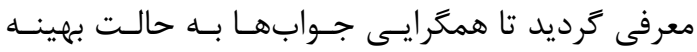

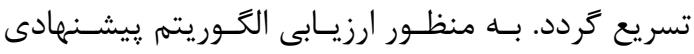

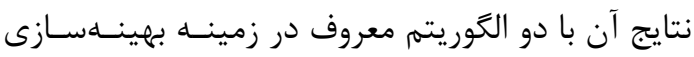

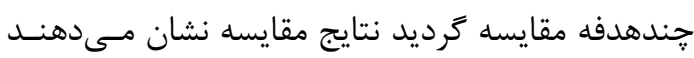
كه الكوريتم ييشنهادى در همخرايى نتايج به جوابهاى معاى

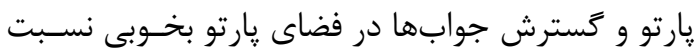

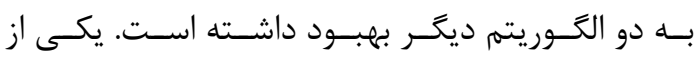
محدوديتهاى اين تحقيق، توليد جــوابهـاى نـامغلوب فراوان است. در تحقيقات آتى مىتوان مدلى نولى را ارائه داد

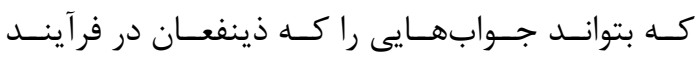
برنامهريزى شـهرى روى آن بـهـ توافـق رسـيدهانـد را از رئ

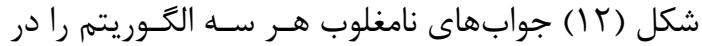
فضاى اهداف نشان مى دهد. با توجه به اين شكل كـاملاً

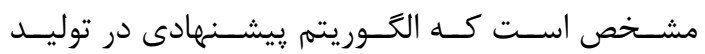
جوابهايى با يراكندگى يكنواخت بهتـــ از دو الخَـوريتم ديخر عمل نموده اسـت. ايسن شـكل نتـايج شـكل (11)

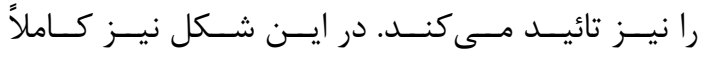

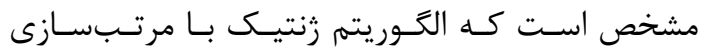
نامغلوب نسخه r در توليد جوابهـاى متنـوع، بهتــر از نسخه ب عمل كرده است.

$$
\text { 9- نتيجه كيرى }
$$

با توجه بـه وجـود اهـداف و قيـود گونـاكون در فرآينـد تخصيص كـاربرىهـاى اراضـى شـهرى، ايسن فرآينــ را

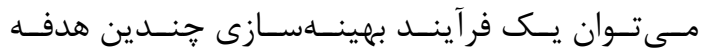

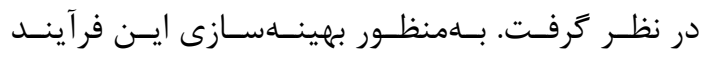
در اين تحقيق يك روش بهينهسازى جندهدفه برمبناى

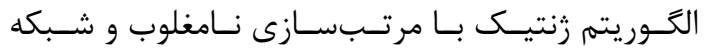
ارائه گرديد. برخى تحقيقات قبلى نيز از مفهـوم شـبكه

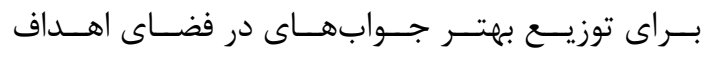
بهره جستهاند. در اين تحقيق نيز مفهوم شبكه به جـاى

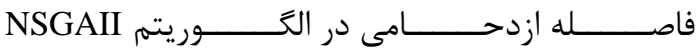
مورد استفاده قرار زرفت. با توجه به ماهيت ساده شبكه 


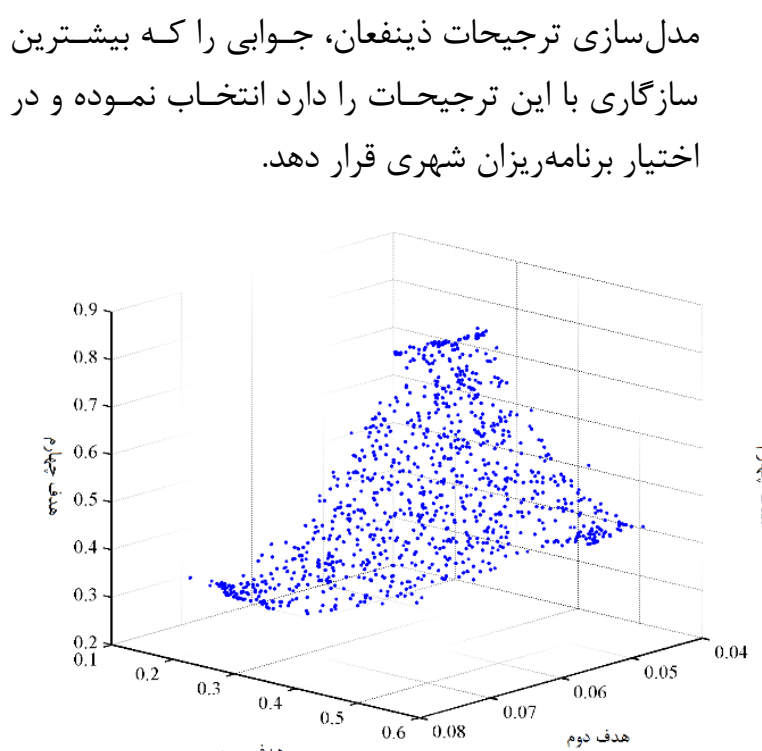

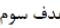

(a)

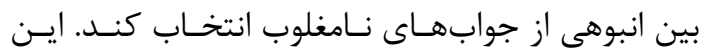

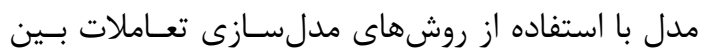

$$
\begin{aligned}
& \text { ذينفعان ماند مدلهاى تعاملى و جندعاملى مى تواند بـاـا }
\end{aligned}
$$

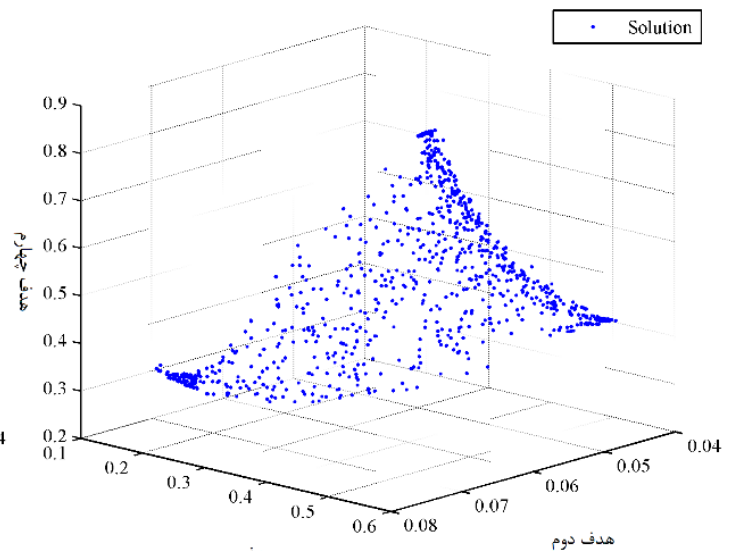

(b)

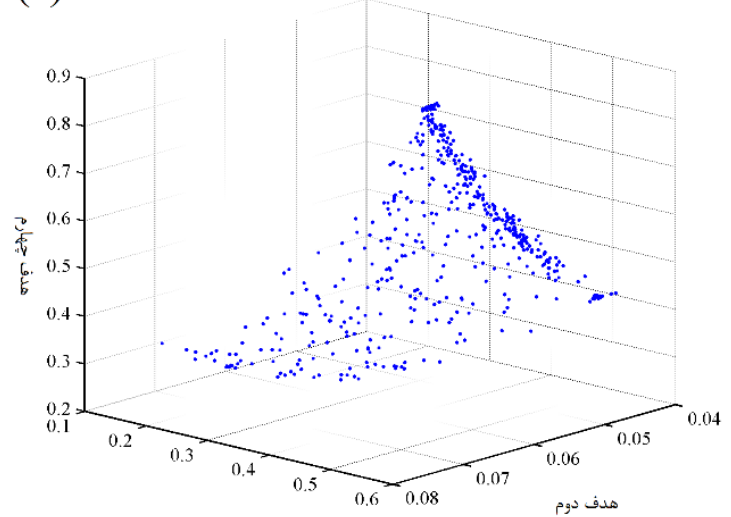

(c)

شكل זا: جوابهاى نامغلوب در فضاى اهداف (a) جوابهاى حاصل از الكَوريتم رِيشنهادى. (b) جوابهاى حاصل الگَوريتم

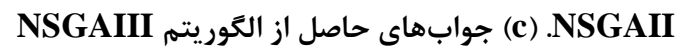

[1] A. Saidnia, Urban land-use (In Persian) vol. Two. Tehran: Publication of Tehran Urban Planning \& Research Center (TUPRC), 1999.

[2] X. Li and L. Parrott, "An improved Genetic Algorithm for spatial optimization of multiobjective and multi-site land use allocation," Computers, Environment and Urban Systems, vol. 59, pp. 184-194, 9// 2016.

[3] G. Arciniegas and R. Janssen, "Spatial decision support for collaborative land use

\section{مراجع}

planning workshops," Landscape and Urban Planning, vol. 107, pp. 332-342, 9/15/ 2012.

[4] X. Li and A. G.-O. Yeh, "Modelling sustainable urban development by the integration of constrained cellular automata and GIS," International Journal of Geographical Information Science, vol. 14, pp. 131-152, 2000.

[5] T. A. Arentze, A. W. Borgers, L. Ma, and H. J. Timmermans, "An agent-based heuristic method for generating land-use plans in 
urban planning," Environment and planning. B, Planning \& design, vol. 37, p. 463, 2010.

[6] K. Cao, M. Batty, B. Huang, Y. Liu, L. Yu, and J. Chen, "Spatial multi-objective land use optimization: extensions to the nondominated sorting genetic algorithm-II," International Journal of Geographical Information Science, vol. 25, pp. 1949-1969, 2011.

[7] G. Arciniegas, "Map-based decision support tools for collaborative land use planning," Free University Amsterdam $\mathrm{PhD}$ thesis, 2012.

[8] P. Pelzer, S. Geertman, P. Pelzer, S. Geertman, R. v. d. van der Heijden, and E. Rouwette, "The added value of Planning Support Systems: A practitioner's perspective," Computers, Environment and Urban Systems, vol. 48, pp. 16-27, 2014.

[9] G. Arciniegas, R. Janssen, and N. Omtzigt, "Map-based multicriteria analysis to support interactive land use allocation," International Journal of Geographical Information Science, vol. 25, pp. 1931-1947, 2011.

[10] S. M. Ghavami, M. Taleai, and T. Arentze, "Socially rational agents in spatial land use planning: A heuristic proposal based negotiation mechanism," Computers, Environment and Urban Systems, vol. 60, pp. 67-78, 11// 2016.

[11] S. Abolhasani, M. Taleai, M. Karimi, and A. Rezaee Node, "Simulating urban growth under planning policies through parcelbased cellular automata (ParCA) model," International Journal of Geographical Information Science, pp. 1-26, 2016.

[12]H. Moah and P. Kanaroglou, "A tool for evaluating urban sustainability via integrated transportation and land use simulation models," Urban Environment, vol. 3, pp. 2846, 2009.

[13]E. Chuvieco, "Integration of linear programming and GIS for land-use modelling," International Journal of Geographical Information Systems, vol. 7, pp. 71-83, 1993/01/01 1993.
[14]A. Haque and Y. Asami, "Optimizing urban land use allocation for planners and real estate developers," Computers, Environment and Urban Systems, vol. 46, pp. 57-69, 2014.

[15] K. Cao, B. Huang, S. Wang, and H. Lin, "Sustainable land use optimization using Boundary-based Fast Genetic Algorithm," Computers, Environment and Urban Systems, vol. 36, pp. 257-269, 2012.

[16]K. Khalili-Damghani, B. AminzadehGoharrizi, S. Rastegar, and B. AminzadehGoharrizi, "Solving land-use suitability analysis and planning problem by a hybrid meta-heuristic algorithm," International Journal of Geographical Information Science, 2014.

[17] J. Porta, J. Parapar, R. Doallo, F. F. Rivera, I. Santé, and R. Crecente, "High performance genetic algorithm for land use planning," Computers, Environment and Urban Systems, vol. 37, pp. 45-58, 2013.

[18] J. C. Aerts, M. van Herwijnen, and T. J. Stewart, "Using simulated annealing and spatial goal programming for solving a multi site land use allocation problem," in International Conference on Evolutionary Multi-Criterion Optimization, 2003, pp. 448463.

[19]Z. Masoomi, M. S. Mesgari, and M. Hamrah, "Allocation of urban land uses by Multi-Objective Particle Swarm Optimization algorithm," International Journal of Geographical Information Science, vol. 27, pp. 542-566, 2013.

[20] R. J. Balling, J. T. Taber, M. R. Brown, and K. Day, "Multiobjective urban planning using genetic algorithm," Journal of Urban Planning and Development, vol. 125, pp. 8699, 1999.

[21]T. J. Stewart, R. Janssen, and M. van Herwijnen, "A genetic algorithm approach to multiobjective land use planning," Computers \& Operations Research, vol. 31, pp. 2293-2313, 2004.

[22] J. C. Aerts and G. B. Heuvelink, "Using 
simulated annealing for resource allocation," International Journal of Geographical Information Science, vol. 16, pp. 571-587, 2002.

[23] X. Liu, X. Li, X. Shi, K. Huang, and Y. Liu, "A multi-type ant colony optimization (MACO) method for optimal land use allocation in large areas," International Journal of Geographical Information Science, vol. 26, 2012.

[24] M. Shifa, H. Jianhua, L. Feng, and Y. Yan, "Land-use spatial optimization based on PSO algorithm," Geo-Spatial Information Science, vol. 14(1), pp. 54-61, 2011.

[25]L. Yang, X. Sun, L. Peng, J. Shao, and T. Chi, "An improved artificial bee colony algorithmfor optimal land-use allocation," International Journal of Geographical Information Science, pp. 1-20, 2015.

[26]M. Mohammadi, M. Nastaran, and A. Sahebgharani, "Development, application, and comparison of hybrid meta-heuristics for urban land-use allocation optimization: Tabu search, genetic, GRASP, and simulated annealing algorithms," Computers, Environment and Urban Systems, vol. 60, pp. 23-36, 11// 2016.

[27] A. Ligmann - Zielinska, R. L. Church, and P. Jankowski, "Spatial optimization as a generative technique for sustainable multiobjective land - use allocation," International Journal of Geographical Information Science, vol. 22, pp. 601-622, 2008.

[28] K. Deb, "Multi-objective optimization," in Search methodologies, ed: Springer, 2014, pp. 403-449.

[29] K. Huang, X. Liu, X. Li, J. Liang, and S. He, "An improved artificial immune system for seeking the Pareto front of land-use allocation problem in large areas," International Journal of Geographical Information Science, vol. 27, pp. 922-946, 2013/05/01 2013.

[30]C. M. Feng and J. J. Lin, "Using a genetic algorithm to generate alternative sketch maps for urban planning," Computers Environment and Urban Systems, vol. 23, pp. 91-108, 1999.

[31] K. Deb and H. Jain, "An evolutionary manyobjective optimization algorithm using reference-point-based nondominated sorting approach, part I: solving problems with box constraints," Evolutionary Computation, IEEE Transactions on, vol. 18, pp. 577-601, 2014.

[32]R. Cheng, Y. Jin, M. Olhofer, and B. Sendhoff, "A Reference Vector Guided Evolutionary Algorithm for Many-Objective Optimization," IEEE Transactions on Evolutionary Computation, vol. 20, pp. 773$791,2016$.

[33] S. Yang, M. Li, X. Liu, and J. Zheng, "A Grid-Based Evolutionary Algorithm for Many-Objective Optimization," IEEE Transactions on Evolutionary Computation, vol. 17, pp. 721-736, 2013.

[34][34]H. Ishibuchi, R. Imada, Y. Setoguchi, and Y. Nojima, "Performance comparison of NSGA-II and NSGA-III on various manyobjective test problems," in 2016 IEEE Congress on Evolutionary Computation (CEC), 2016, pp. 3045-3052.

[35]T. Chiang, "nsga3cpp: A C++ implementation of NSGA-iii," ed, 2014.

[36] Y. Yuan, H. Xu, and B. Wang, "An improved NSGA-III procedure for evolutionary many-objective optimization," presented at the Proceedings of the 2014 Annual Conference on Genetic and Evolutionary Computation, Vancouver, BC, Canada, 2014.

[37][37]B. Li, J. Li, K. Tang, and X. Yao, "Many-objective evolutionary algorithms: A survey," ACM Computing Surveys (CSUR), vol. 48, p. 13, 2015.

[38] K. Cao and X. Ye, "Coarse-grained parallel genetic algorithm applied to a vector based land use allocation optimization problem: the case study of Tongzhou Newtown, Beijing, China," Stochastic Environmental Research and Risk Assessment, vol. 27, pp. 
1133-1142, 2013.

[39]T. J. Stewart and R. Janssen, "A multiobjective GIS-based land use planning algorithm," Computers, Environment and Urban Systems, vol. 46, pp. 25-34, 2014.

[40] M. Taleai, A. Sharifi, R. Sliuzas, and M. Mesgari, "Evaluating the compatibility of multi-functional and intensive urban land uses," International Journal of Applied Earth Observation and Geoinformation, vol. 9, pp. 375-391, 12// 2007.

[41]H. Jain and K. Deb, "An evolutionary manyobjective optimization algorithm using reference-point based nondominated sorting approach, part II: handling constraints and extending to an adaptive approach," Evolutionary Computation, IEEE Transactions on, vol. 18, pp. 602-622, 2014.

[42]E. Mezura-Montes and C. A. C. Coello, "Constraint-handling in nature-inspired numerical optimization: past, present and future," Swarm and Evolutionary Computation, vol. 1, pp. 173-194, 2011.

[43] J. Maleki, F. Hakimpour, and Z. Masoumi, "A Parcel-Level Model for Ranking and Allocating Urban Land-Uses," ISPRS International Journal of Geo-Information, vol. 6, p. 273, 2017.

[44] C. E. Farnahad, "Development pattern of district 7 of Tehran (In Persian)," Orderd by
Tehran municipality2005.

[45] K. Deb, A. Pratap, S. Agarwal, and T. Meyarivan, "A fast and elitist multiobjective genetic algorithm: NSGA-II," Evolutionary Computation, IEEE Transactions on, vol. 6, pp. 182-197, 2002.

[46] M. Köppen and K. Yoshida, "Substitute distance assignments in NSGA-II for handling many-objective optimization problems," in Evolutionary Multi-Criterion Optimization, 2007, pp. 727-741.

[47] V. Chankong and Y. Y. Haimes, Multiobjective Decision Making Theory and Methodology: New York: North-Holland, 1983.

[48] Maab-Consulting-Engineers, Definitions and concepts of urban land-uses and determining the per capita (In Persian): Iran's Supreme Council for Planning and Architecture, 2010.

[49] M. Habibi and S. Masaeli, Urban land uses per capita (In Persian). Tehran: National Land and Housing Organization, 1999.

[50] K. Deb, Multi-objective optimization using evolutionary algorithms vol. 16: John Wiley \& Sons, 2001. 


\title{
Urban Land-Use Allocation By A Cell-based Multi-Objective Optimization Algorithm
}

\author{
Jamshid Maleki $^{1}$, Farshad Hakimpour ${ }^{2}$, Zohreh Masoumi ${ }^{* 3}$ \\ 1- Ph.D. student of Geospatial Information Systems (GIS) in School of Surveying and Geospatial Engineering, College of Engineering, University \\ of Tehran \\ 2-Assisstant professor in School of Surveying and Geospatial Engineering, College of Engineering, University of Tehran \\ 3- Assisstant professor in Department of Earth Sciences, University in Advanced Studies in Basic Sciences
}

\begin{abstract}
Allocating urban land-uses to land-units with regard to different criteria and constraints is considered as a spatial multiobjective problem. Generating various urban land-use layouts with respect to defined objectives for urban land-use allocation can support urban planners in confirming appropriate layouts. Hence, in this research, a multi-objective optimization algorithm based on grid is proposed to generate well-distributed solutions in objective space. In order to preserve diversity in Pareto front approximation, a grid is defined in objective space. The cells of this grid cluster the solutions and determine the suitable solutions for next generation in optimization process. The land-uses of region 1 of the district 7 of Tehran is used to assess the efficiency of the algorithm in optimizing urban land-use allocation. The results of the proposed algorithm are compared with the results of Non-dominated Sorting Genetic Algorithm II and III (NSGA-II and NSGA-III). Comparing the results indicate that the proposed algorithm acts better than NSGA-II and NSGA-III in preserving diversity and improving the convergence of the solutions in Pareto front.
\end{abstract}

Key words: Urban Land-use Allocation, Grid-based NSGA-II, Multi-objective Optimization, Spatial Planning Support Systems.

Correspondence Address. Department of earth sciences, Institute for advanced studies in basic sciences, No. 444, Prof. Yousef Sobouti Blvd. P. O. Box 45195-1159 Zanjan Iran,

Tel: $024-33153396$

Email: z.masoumi@iasbs.ac.ir 